\title{
The climate change signal in the Mediterranean Sea in a regionally coupled atmosphere-ocean model
}

\author{
Ivan M. Parras-Berrocal ${ }^{1}$, Ruben Vazquez ${ }^{1}$, William Cabos ${ }^{2}$, Dmitry Sein ${ }^{3,4}$, Rafael Mañanes ${ }^{1}$, Juan Perez-Sanz ${ }^{2}$, \\ and Alfredo Izquierdo ${ }^{1}$ \\ ${ }^{1}$ Instituto Universitario de Investigación Marina (INMAR), University of Cádiz, Puerto Real, Cádiz 11510, Spain \\ ${ }^{2}$ Department of Physics and Mathematics, University of Alcalá, Alcalá de Henares 28801, Spain \\ ${ }^{3}$ Alfred Wegener Institute for Polar and Marine Research, Bremerhaven 27570, Germany \\ ${ }^{4}$ Shirshov Institute of Oceanology, Russian Academy of Science, Moscow, Russia
}

Correspondence: Ivan M. Parras-Berrocal (ivan.parras@uca.es)

Received: 26 April 2019 - Discussion started: 3 May 2019

Revised: 4 March 2020 - Accepted: 3 May 2020 - Published: 25 June 2020

\begin{abstract}
We analyze the climate change signal in the Mediterranean Sea using the regionally coupled model REMO-OASIS-MPIOM (ROM; abbreviated from the regional atmosphere model, the OASIS3 coupler and the Max Planck Institute Ocean Model). The ROM oceanic component is global with regionally high horizontal resolution in the Mediterranean Sea so that the water exchanges with the adjacent North Atlantic and Black Sea are explicitly simulated. Simulations forced by ERA-Interim show an accurate representation of the present Mediterranean climate. Our analysis of the RCP8.5 (representative concentration pathway) scenario using the Max Planck Institute Earth System Model shows that the Mediterranean waters will be warmer and saltier throughout most of the basin by the end of this century. In the upper ocean layer, temperature is projected to have a mean increase of $2.7^{\circ} \mathrm{C}$, while the mean salinity will increase by $0.2 \mathrm{psu}$, presenting a decreasing trend in the western Mediterranean in contrast to the rest of the basin. The warming initially takes place at the surface and propagates gradually to deeper layers. Hydrographic changes have an impact on intermediate water characteristics, potentially affecting the Mediterranean thermohaline circulation in the future.
\end{abstract}

\section{Introduction}

The Mediterranean Sea is expected to be among the world's most prominent and vulnerable climate change "hot spots" (Giorgi, 2006; Cramer et al., 2018). As such, the region is an optimal case study site to test new approaches to bridge the gap between science and society by using a sound scientific basis of climate information which is applicable to a broad range of vulnerable sectors.

The Mediterranean is a regional sea surrounded by Africa, Europe and Asia and divided into two subbasins (eastern and western) through a sill that does not exceed $400 \mathrm{~m}$ depth between Sicily and the African continent. The freshwater balance in the Mediterranean basin is negative since the evaporation exceeds precipitation and river runoff (SanchezGomez et al., 2011). This deficit is compensated for by a net inflow of water through the Strait of Gibraltar and the Dardanelles. The region is located in a transitional area between tropical and midlatitudes and presents a complex orography and coastlines, where intense air-sea and land-sea interactions take place. These intense air-sea interactions together with the inflow of Atlantic Water drive the Mediterranean thermohaline circulation (MTHC) (Fig. 1), suggesting that atmosphere-ocean regionally coupled models (AOR$\mathrm{CMs}$ ) could be conducive to the study of atmospheric and oceanic processes in the Mediterranean Sea.

Different AORCMs with typical horizontal resolutions of $25-50 \mathrm{~km}$ in the atmosphere and $10-20 \mathrm{~km}$ in the ocean have been developed to study the climate of the Mediterranean 


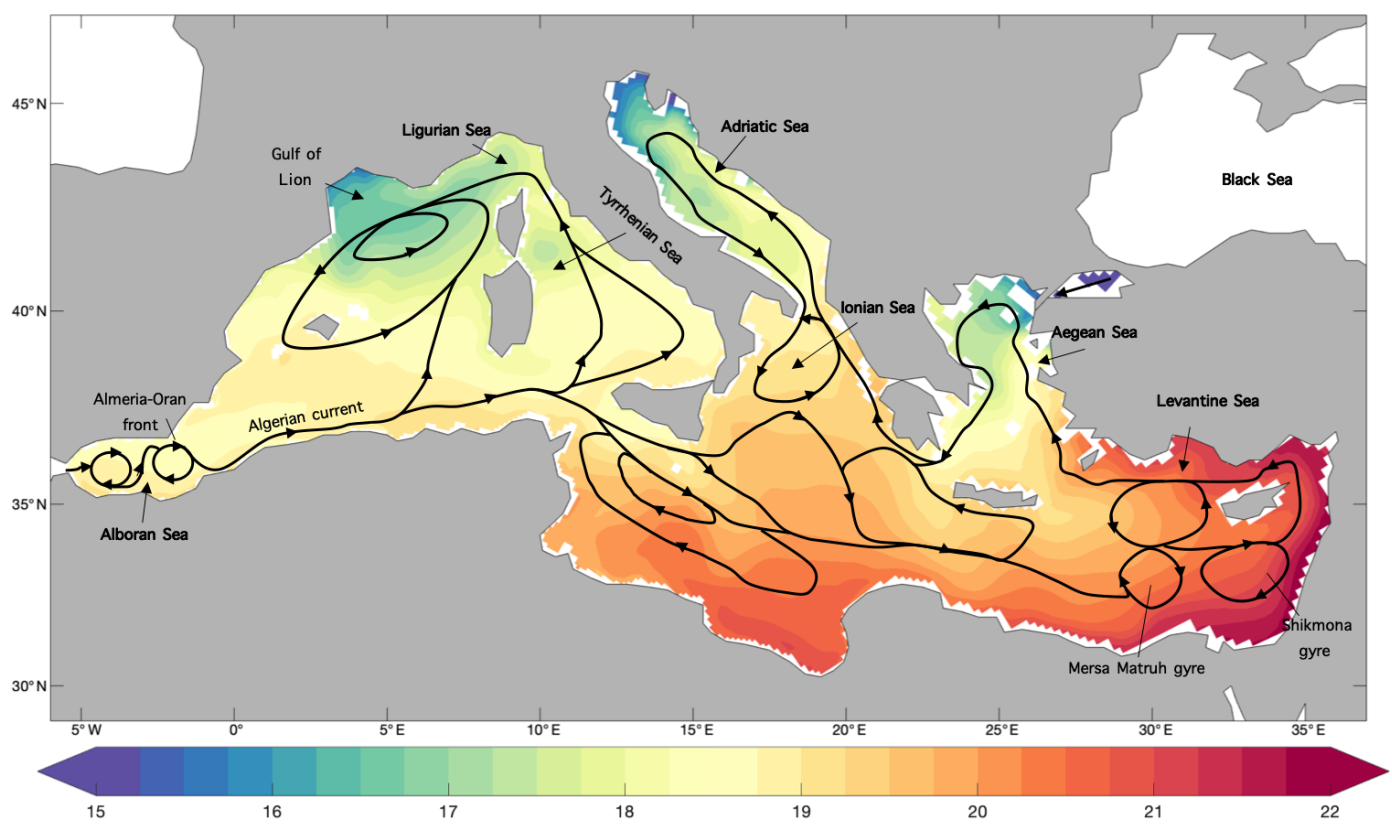

Figure 1. Mediterranean basin: 1980-2012 mean SST $\left({ }^{\circ} \mathrm{C}\right)$ and upper ocean currents (based on Tomczak and Godfrey, 1994).

Sea (Somot et al., 2008; L'Hévéder et al., 2013; Sevault et al., 2014; Cavicchia et al., 2015; Darmaraki et al., 2019). Akhtar et al. (2018) found that higher horizontal resolutions $(9 \mathrm{~km})$ in the atmosphere improve the simulation of the wind and the turbulent heat fluxes, although they conclude that higher-resolution models do not perform better in all aspects than coarser configurations. Somot et al. (2008) developed the Sea Atmosphere Mediterranean Model (SAMM), presenting a new concept of AORCMs through the coupling of the atmospheric global model (ARPEGE; Déqué and Piedelievre, 1995) with the regional, high-resolution $(10 \mathrm{~km})$ ocean model (OPAMED; Somot et al., 2006). Their results under the A2 (IPCC, 2000) climate change scenario showed an increase in temperature and salinity both in shallow $\left(3.1^{\circ} \mathrm{C}\right.$ and $\left.0.48 \mathrm{psu}\right)$ and in deeper $\left(1.5^{\circ} \mathrm{C}\right.$ and $\left.0.23 \mathrm{psu}\right)$ layers of the Mediterranean Sea (Somot et al., 2006) by the end of the 21st century. In 2013, the European CIRCE project was launched (Gualdi et al., 2013) in order to facilitate coordination among the scientific community responsible for regional climate modeling in the Mediterranean. The beginnings of CIRCE can be traced back to the work of Dubois et al. (2012), who compared different AORCMs and regional climate models (RCMs). In addition, these authors analyzed a projection (1950-2050) of the Mediterranean climate under the A1B scenario simulated by an ensemble of five coupled regional models. For the first time, realistic atmosphereocean net flows were obtained, which predicted a Mediterranean surface warming between 0.8 and $2.0^{\circ} \mathrm{C}$. Shaltout and Omstedt (2014) analyzed the Mediterranean sea surface temperature (SST) for 2005 to 2100 from the Coupled Model Intercomparison Project Phase 5 (CMIP5) model ensemble under the RCP2.6, RCP4.5, RCP6.0 and RCP8.5 (representative concentration pathway) scenarios (Taylor et al., 2012). The CMIP5 ensemble means projected SST warming under all considered scenarios (from $0.5^{\circ} \mathrm{C}$ under RCP2.6 to $2.6^{\circ} \mathrm{C}$ under RCP8.5). The authors concluded that the warming was mainly controlled by the amount of greenhouse gas emissions. More recently, Adloff et al. (2015) estimated that by the end of the 21st century the mean Mediterranean SST and sea surface salinity (SSS) will increase between 1.73 and $2.97^{\circ} \mathrm{C}$ and 0.48 and $0.89 \mathrm{psu}$, respectively. Their results were based on an ensemble of six simulations performed with different configurations of the NEMOMED8 (Beuvier et al., 2010) ocean model under different scenarios. Darmaraki et al. (2019) employed an ensemble of 17 fully coupled atmosphere-ocean simulations to study the evolution of SST and marine heat waves in the Mediterranean Sea for the period $1976-2100$. The ensemble mean showed a $3.1^{\circ} \mathrm{C}$ increase in the Mediterranean mean SST under the RCP8.5 scenario by the end of the century. By 2100 projections showed stronger and more intense Mediterranean marine heat waves. Most of the above-mentioned studies show that the driving factors prescribed in the emissions scenarios condition the expected warming of the Mediterranean Sea.

These modeling efforts are coordinated through the Med-CORDEX initiative (Ruti et al., 2015; https://www. medcordex.eu, last access: 10 January 2019), which is the regional climate modeling task force of the HyMeX program (https://www.hymex.org, last access: 10 January 2019). In the framework of Med-CORDEX, a broad range of new reference datasets for regional climate evaluation are being compiled, and the evaluation of new fully coupled re- 
gional climate models for understanding the processes that are responsible for the Mediterranean climate variability and trends is being carried out (Somot et al., 2018).

In these models, the oceanic component of the AORCMs is also regional. One of the main problems of AORCMs is the prescription of lateral boundary conditions for the regional ocean models, which are mainly based on monthly means from global ocean reanalysis datasets (e.g., HYCOM; Metzger et al., 2014), damping the ocean dynamics on timescales of less than 1 month. Those regional climate models should effectively resolve the small-scale processes that are not adequately represented in the coarser model data used as boundary conditions. This creates inconsistencies between the regional model solution and the external data that can be avoided with the consideration of a global ocean model with refined resolution within the coupled domain (Sein et al., 2015). Such an approach was employed by Izquierdo and Mikolajewicz (2019) in an ocean-only process study to account for the impact of the interaction of processes of different space and timescales on the Mediterranean Outflow Water (MOW) spreading, which is of particular importance in the Strait of Gibraltar and the Gulf of Cádiz. The use of an ocean global model (Max Planck Institute Ocean Model, MPIOM) in the REMO-OASIS-MPIOM (ROM; abbreviated from the regional atmosphere model, the OASIS3 coupler and the Max Planck Institute Ocean Model) coupled system model avoids the problems associated with the open boundary conditions for the Mediterranean Sea, allowing for the study of processes taking place in the Mediterranean region but originating in the North Atlantic Ocean. This study aims to contribute to the Med-CORDEX initiative with a first detailed evaluation of high-resolution atmosphereocean simulations for the present climate with the coupled ROM model. Furthermore, we analyze the evolution of the Mediterranean Sea under the RCP8.5 scenario with boundary conditions taken from CMIP5 simulation using the Max Planck Institute Earth System Model (MPI-ESM). In particular, we focus on ocean properties such as SST and SSS and their evolution towards the end of the 21 st century.

The objectives of this study can be summarized as follows:

i. assess the skill of ROM in reproducing the observed Mediterranean Sea regional climate when driven by ERA-Interim reanalysis

ii. examine the value that high-resolution ROM adds compared to the driving model (MPI-ESM)

iii. assess the projected climate change signal in the Mediterranean Sea under the RCP8.5 scenario.

This article is organized as follows: a general description of our coupled model and each of its components is presented in Sect. 2. In Sect. 3, we present the results of the model validation followed by the coupled simulations for the Mediterranean region. Finally, Sect. 4 contains the discussion and the conclusions are outlined in Sect. 5.

\section{Methods}

ROM (Sein et al., 2015) comprises the regional atmosphere model (REMO; Jacob et al., 2001), the Max Planck Institute Ocean Model (MPIOM; Marsland et al., 2003; Jungclaus et al., 2013), the Hamburg Ocean Carbon Cycle (HAMOCC) model (Maier-Reimer et al., 2005), the hydrological discharge (HD) model (Hagemann and Gates, 1998, 2001), the soil model of REMO (Rechid and Jacob, 2006) and a dynamic thermodynamic sea ice model (Hibler, 1979), which are coupled via the OASIS3 (Valcke, 2013) coupler and abbreviated as ROM from REMO-OASIS-MPIOM.

\subsection{Atmosphere (REMO)}

The atmospheric component of ROM is REMO. Its dynamic core and discretization in space and time are based on the Europe model of the German Weather Service (Majewski, 1991). The physical parameterizations are taken from the global climate model ECHAM versions 4 and 5 (Roeckner et al., 1996, 2003). The variables that exchange information between REMO and MPIOM via OASIS are $10 \mathrm{~m}$ wind velocity, wind stress over water, wind stress over sea ice, liquid precipitation, solid precipitation, net shortwave radiation, total heat flux over water, conductive heat flux and residual heat flux (Fig. 2a). To avoid the largely different extensions of the grid cells close to the poles, REMO uses a rotated grid with the Equator of the rotated system in the middle of the model domain. The horizontal discretization is carried out on the Arakawa C-grid and the hybrid vertical coordinates are defined according to Simmons and Burridge (1981). Our version of REMO does not include an aerosol module. The information about aerosols is based on the climatology from Tanre et al. (1984). Here, the spatial distributions of the optical thickness of land, sea, urban and desert aerosols, as well as well-mixed tropospheric and stratospheric background aerosols, are represented. More information about the parameterizations in the atmospheric component can be found in Sein et al. (2015).

\subsection{Ocean (MPIOM)}

The oceanic component of ROM is the MPIOM developed at the Max Planck Institute for Meteorology (Hamburg, Germany). MPIOM is a free surface, primitive equations ocean model, which uses the Boussinesq and incompressibility approximations. MPIOM is formulated on an orthogonal curvilinear Arakawa C-grid (Arakawa and Lamb, 1977) with variable spatial resolution. This grid allows for the placement of the poles over land, thus removing the numerical singularity associated with the convergence of meridians at the geographical North Pole. An additional advantage of the curvilinear grid is that a higher resolution in the region of interest can be obtained while maintaining a global domain. Using the global ocean model alleviates issues related to ocean 
(a)

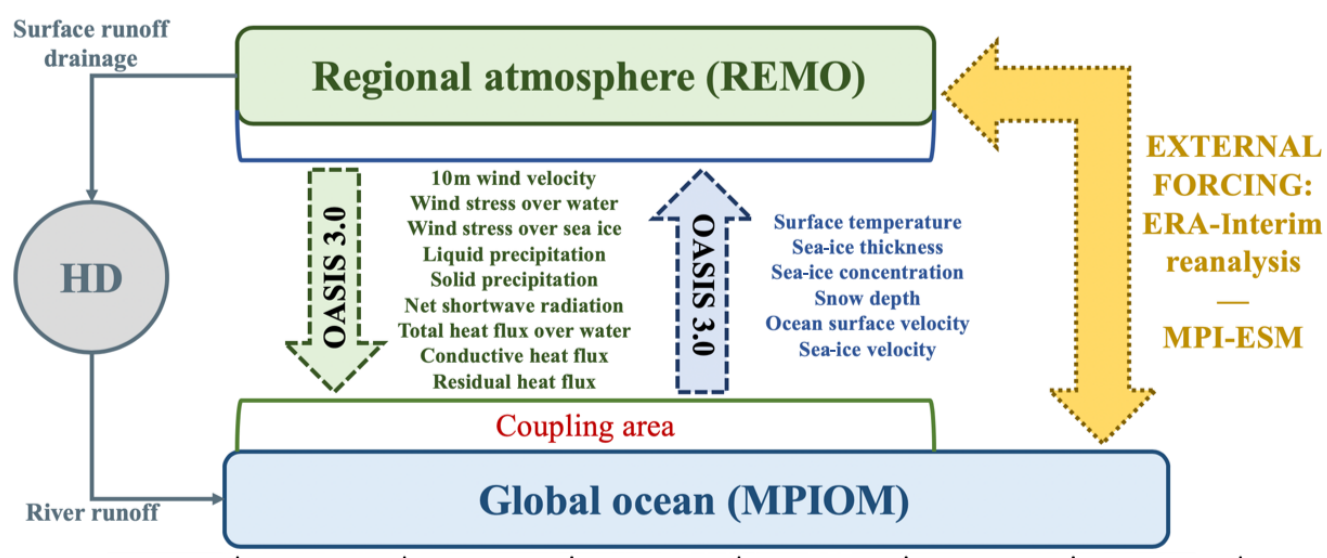

(b)

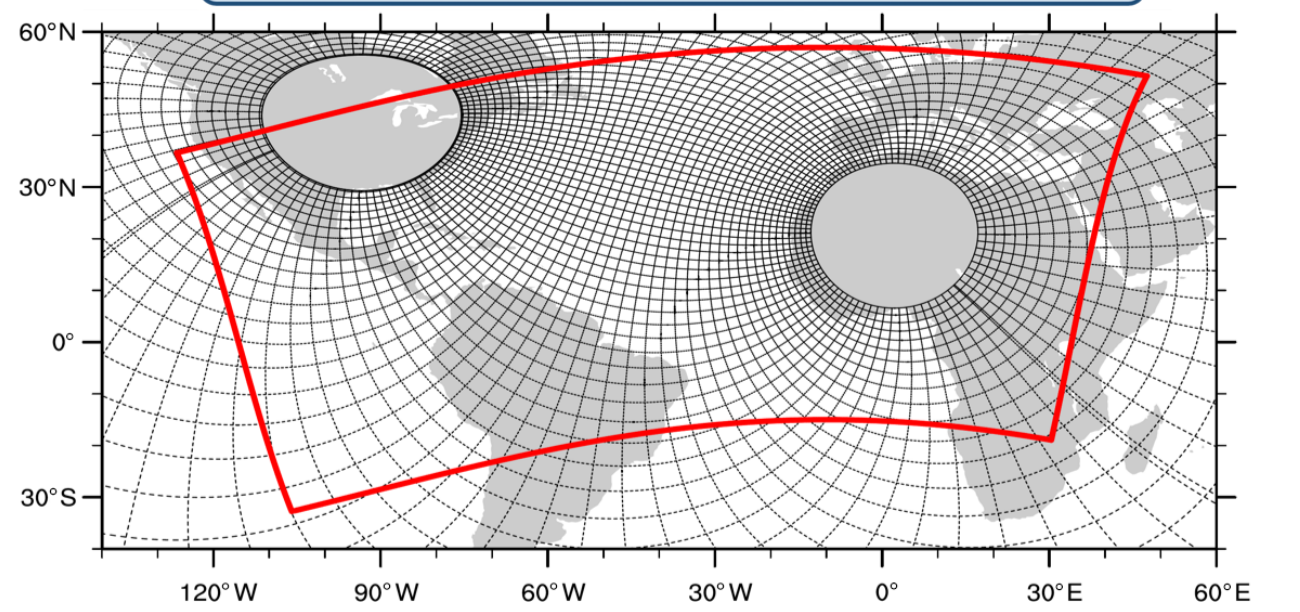

Figure 2. (a) ROM coupling scheme and (b) atmospheric and oceanic ROM grids. MPIOM variable resolution grid (black lines, drawn every 12th) and REMO domain (red line).

open boundary conditions and provides an additional "degree of freedom" in the model setup and tuning, which can help increase the performance of the ocean component within the region of interest. The model parameterizations and setup are described in Sein et al. (2015).

\subsection{ROM configuration and experiment setup}

Figure 2a shows the coupling scheme used in ROM. In the region covered by REMO, the atmosphere and the ocean interact while the rest of the global ocean is driven by energy fluxes, momentum and mass from global atmospheric data used as external forcing. In the experiments analyzed here, data from ERA-Interim reanalysis (Dee et al., 2011) and MPI-ESM-LR (low resolution) (Giorgetta et al., 2013) are used to provide lateral boundary conditions to REMO and to force MPIOM outside the coupling region.

The MPIOM grid used in this setup is represented by black lines in Fig. 2b. In the Mediterranean region, the highest horizontal resolution of MPIOM is $7 \mathrm{~km}$ (south of the Alboran Sea) while the lowest resolution is $25 \mathrm{~km}$ (eastern coasts of the Mediterranean Sea). MPIOM has 40 vertical $z$ levels with increasing layer thickness with depth with the first layer's nominal thickness being $16 \mathrm{~m}$. The spin-up of MPIOM was done according to the procedure described in Sein et al. (2015). In the stand-alone mode, MPIOM is started with climatological temperature and salinity data (Levitus et al., 1998). Subsequently, it is integrated four times through the 1958-2002 period forced by ERA-40. For the coupled runs, the model is started from the final state reached in the last stand-alone run and integrated again, forced two times by ERA-40 and one time by ERA-Interim reanalysis (19792012).

The REMO domain covers the North and tropical Atlantic, a large part of Africa, South America, and the Mediterranean region (red line, Fig. 2b) with a resolution of approximately $25 \mathrm{~km}$ on a rotated grid and a time step of $120 \mathrm{~s}$. More information about the ROM-coupled system is summarized in Table 1. The HD model (global domain) computes the river discharge at $0.5^{\circ}$ resolution, and an information exchange takes place every $60 \mathrm{~min}$, while HD interacts with MPIOM and REMO every $24 \mathrm{~h}$ (Fig. 2a).

In this study, 30-year time series from three different experiments have been analyzed. The first simulation, ROM_P0, was forced by ERA-Interim for the time period 
Table 1. Characteristics of ROM atmosphere-ocean regionally coupled model used in this study. Modified from Darmaraki et al. (2019). For details see Sein et al. (2015).

\begin{tabular}{ll}
\hline Institute & AWI/GERICS \\
Driving global climate model & MPI-ESM-LR \\
Med. Sea model & MPIOM \\
Ocean res. & $7-25 \mathrm{~km}$ \\
Num. of $z$ levels (ocean) & 40 \\
SST (1st layer depth) & $16 \mathrm{~m}$ \\
Time step (ocean) & $900 \mathrm{~s}$ \\
Atmosphere model & REMO \\
Atmosphere Res. & $25 \mathrm{~km}$ \\
Time step (atmosphere) & $120 \mathrm{~s}$ \\
Coupling frequency & $60 \mathrm{~min}$ \\
\hline
\end{tabular}

1980-2012 and was used to assess the skill of ROM in reproducing the observed regional climate over the Mediterranean Sea. In order to present an integrated vision of the impact of climate change on the Mediterranean Sea, we dynamically downscaled the MPI-ESM-LR historical simulation, covering the period 1950-2005 (for our analysis we take ROM_P1 from 1976 to 2005), and the climate change projection for 2006-2099 (for our analysis we take ROM_P2 from 2070 to 2099) under the Representative Concentration Pathway 8.5 (RCP8.5) scenario.

The driving model, MPI-ESM, has been used in different configurations for CMIP5 in a series of climate change experiments (Giorgetta et al., 2013). MPI-ESM is composed of ECHAM 6 (Stevens et al., 2013) for atmosphere and MPIOM (Jungclaus et al., 2013) for ocean, as well as JSBACH (Reick et al., 2013) for terrestrial biosphere and HAMOCC (Ilyina et al., 2013) for the ocean's biogeochemistry. The coupling of the atmosphere, ocean and land surface is made possible by the OASIS3 (Valcke, 2013) coupler. MPI-ESM-LR (low resolution) uses T63 $\left(1.9^{\circ}\right)$ horizontal resolution and 47 hybrid sigma-pressure levels for the atmosphere and a bipolar grid with $1.5^{\circ}$ horizontal resolution (near the Equator) for the ocean, while the MPI-ESM-MR (mixed resolution) version has the same horizontal resolution in the atmosphere, although it doubles the number of vertical levels in the atmosphere and decreases the horizontal grid spacing of the ocean to $0.4^{\circ}$ by means of a tripolar grid (Giorgetta et al., 2013).

We have used MPI-ESM-LR to force ROM in experiments ROM_P1 and ROM_P2 because MPI-ESM-LR was used in a wider set of CMIP5 experiments and with more realizations than MPI-ESM-MR (Giorgetta et al., 2013). Both present the same horizontal resolution in the atmosphere, and, although MPI-ESM-MR has a higher vertical resolution mainly in the upper troposphere and lower stratosphere, the main differences in the simulations can be found in the middle atmosphere (Stevens et al, 2013). According to a recent benchmarking exercise of CMIP5 models (Lauer et al., 2017), their overall performance is quite similar. Jungclaus et al. (2013) provided a detailed description and evaluation of the ocean performance of MPI-ESM-LR and MPI-ESM-MR and concluded that both behave similarly in many aspects, although MPI-ESM-LR simulated the Labrador Sea and the North Atlantic more accurately at least in the mean state and its variability.

\subsection{Validation methodology}

The ROM-simulated present Mediterranean climate is analyzed in terms of mean state, seasonal cycle and interannual variability of several atmospheric and oceanic variables. For the ROM atmospheric component (REMO), three representative variables were chosen: mean sea level pressure (MSLP), near-surface temperature (T2m) and total precipitation. For the ocean component (MPIOM), sea surface temperature (SST), sea surface salinity (SSS), sea surface height (SSH) and the subsurface current velocity are considered. These fields are compared to gridded data from different sources (interpolated observed data and reanalysis) to evaluate the ROM's ability to simulate the present Mediterranean climate (Table 2).

For MSLP and T2m, we compare the output of ROM with ERA-Interim reanalysis. The ERA-Interim data assimilation system uses a 2006 release of the Integrated Forecasting System (IFC) developed jointly by ECMWF and Météo-France. The spatial resolution of the dataset is approximately $80 \mathrm{~km}$ (T255 spectral) on 60 vertical levels from the surface up to $0.1 \mathrm{hPa}$ (Dee et al., 2011); data can be freely accessed at https://www.ecmwf. int/en/research/climate-reanalysis/era-interim (last access: 13 February 2020). Total precipitation is validated against the Tropical Rainfall Measuring Mission (TRMM; Huffman et al., 2014) dataset, a joint mission between NASA and the Japan Aerospace Exploration Agency (JAXA) to study rainfall for weather and climate research.

Three datasets were used for the evaluation of the SST: ERA-Interim, EN4 and OISST. EN4 was derived by Good et al. (2013), who carried out a $1^{\circ}$ monthly objective analysis from ocean temperature and salinity bathythermograph profiles (mechanical bathythermograph, MBT; expendable bathythermograph, XBT). The version EN4.1.1 used here includes the improvements of the estimation of MBT's and XBT's downward velocities developed by Gouretski and Reseghetti (2010). The NOAA's daily Optimum Interpolation Sea Surface Temperature version 2 (OISST; Reynolds et al., 2007) combines observations from different platforms (satellites, ships, buoys) on a regular global grid $1 / 4^{\circ} \times 1 / 4^{\circ}$. The OISST dataset offers an accurate representation of the sea surface (Ferster et al., 2018) and is widely used in the evaluation of regional climate models (e.g., L'Hévéder et al., 2013; Akhtar et al., 2019; Cabos et al., 2019).

For SSS, we used the following two datasets: EN4 v.4.1.1 (Good et al., 2013) and MEDSEA_REANALYSIS_PHY_006_009 (Fratianni et al., 
Table 2. Datasets used in the ROM validation.

\begin{tabular}{lllll}
\hline & Parameters & Period & Spatial resolution & Datasets \\
\hline \multirow{2}{*}{ Atmosphere } & MSLP & $1980-2012$ & $80 \mathrm{~km}(\mathrm{~T} 255$ spectral) & ERA-Interim (Dee et al., 2011) \\
& T2m & $1980-2012$ & $80 \mathrm{~km}(\mathrm{~T} 255$ spectral) & ERA-Interim (Dee et al., 2011) \\
& Precipitation & $1997-2012$ & $1 / 4^{\circ} \times 1 / 4^{\circ}$ & TRMM (Huffman et al., 2014) \\
\hline \multirow{2}{*}{ Ocean } & SST & $1982-2012$ & $1 / 4^{\circ} \times 1 / 4^{\circ}$ & OISST (Reynolds et al., 2007) \\
& $1980-2012$ & $80 \mathrm{~km}(\mathrm{~T} 255$ spectral) & ERA-Interim (Dee et al., 2011) \\
& $1980-2012$ & $1^{\circ} \times 1^{\circ}$ & EN4 v.4.1.1 (Good et al., 2013; \\
& & & Gouretski and Reseghetti, 2010) \\
\cline { 2 - 5 } & \multirow{2}{*}{ SSS } & $1980-2012$ & $1.5^{\circ} \times 1.5^{\circ} / 0.4^{\circ} \times 0.4^{\circ}$ & MPI-ESM-LR and MPI-ESM-MR (Giorgetta et al., 2013) \\
& $1980-2012$ & $1^{\circ} \times 1^{\circ}$ & EN4 v.4.1.1 (Good et al., 2013; \\
& & & Gouretski and Reseghetti, 2010) \\
& $1980-2012$ & $1 / 16^{\circ} \times 1 / 16^{\circ}$ & CMEMS (Fratianni et al., 2015) \\
& $1980-2012$ & $1.5^{\circ} \times 1.5^{\circ} / 0.4^{\circ} \times 0.4^{\circ}$ & MPI-ESM-LR and MPI-ESM-MR (Giorgetta et al., 2013) \\
\hline
\end{tabular}

2015), implemented by the Copernicus Marine Environment Monitoring Service (CMEMS) with a $1 / 16^{\circ}$ horizontal resolution in the Mediterranean.

The potential of ROM to improve the simulation of the regional Mediterranean Sea climate is assessed by comparisons with the MPI-ESM outputs (MPI-ESM-LR and MPIESM-MR).

\section{Results}

In this section, a selection of key fields corresponding to the period 1980-2012 of ROM forced by ERA-Interim (ROM_P0) is presented. In a second step, changes in the Mediterranean Sea under RCP8.5 conditions are estimated from the analysis of differences between the present climate (1976-2005, ROM_P1) and the climate projection (20702099, ROM_P2) carried out by ROM driven by MPI-ESMLR.

\subsection{Atmosphere validation}

Mean sea level pressure (MSLP) is a good indicator of largescale circulation which influences near-surface temperature (T2m) and precipitation distributions. Erroneous MSLP gradients lead to an erroneous regional wind circulation and can also have a strong effect on ocean circulation (Sein et al., 2015). Figure $3 a$ and $b$ display the biases of modeled MSLP with respect to ERA-Interim for the boreal winter (defined as December, January and February; DJF) and summer (defined as June, July and August; JJA) in the 1980-2012 period (ROM_P0). ROM_P0 provides a good agreement with ERA-Interim MSLP, showing maximum deviations smaller than $3 \mathrm{hPa}$ over most of the domain for both seasons. The strongest departures can be found in DJF due to an overestimation of the Azores high during the winter months. Those differences could be attributed partly to REMO parameter- izations, but a more important role could be played by the deficiencies in the simulated ocean circulation in the North Atlantic, which result in a region of cold SST bias centered east of the Flemish Cap (not shown). Jungclaus et al. (2013) consider this cold bias appearing in MPI-ESM-LR and MPIESM-MR to be a persistent feature in state-of-the-art climate models, where the coarse resolution prevents a proper representation of the Gulf Stream separation (Dengg et al., 1996), although they also mention other possible causes. Nonetheless, these relatively small deviations imply a small change in terms of regional wind circulation. During summer months (Fig. 3b) MSLP biases are much smaller over the Mediterranean.

Figure $3 \mathrm{c}$ and $\mathrm{d}$ show T2m biases for DJF and JJA. For both seasons, the departures are typically below $3.0^{\circ} \mathrm{C}$ over most of the coupled domain except for the Alps, the Pyrenees, the Atlas Mountains, the Caucasus and the Armenian highlands (Fig. 3c and d). This disagreement can be attributed to differences in the resolution of orographic features. Winter months show the largest T2m biases located close to the Mediterranean coastline.

At first glance, ROM_P0 generally underestimates the simulated cumulative precipitation over most of the Mediterranean region for the both winter and summer seasons. The largest discrepancies for DJF are located over the Black Sea, the Adriatic Sea and the Gulf of Lion (Fig. 3e), where negative anomalies can reach $3 \mathrm{~mm} \mathrm{~d}^{-1}$. Moreover, it is worth stating that during the same period the total precipitation was overestimated in regions linked to significant topographic reliefs (e.g., the Alps). Some coastal areas also showed positive anomalies that are most likely related to the transport of precipitable water, which is influenced by the simulated evaporation over the ocean (atmosphere-ocean coupling). In the very dry Mediterranean summer season, ROM_P0 shows a clear tendency to underestimate the precipitation (Fig. 3f). Over the ocean, this bias can be related to the cold SST bias 

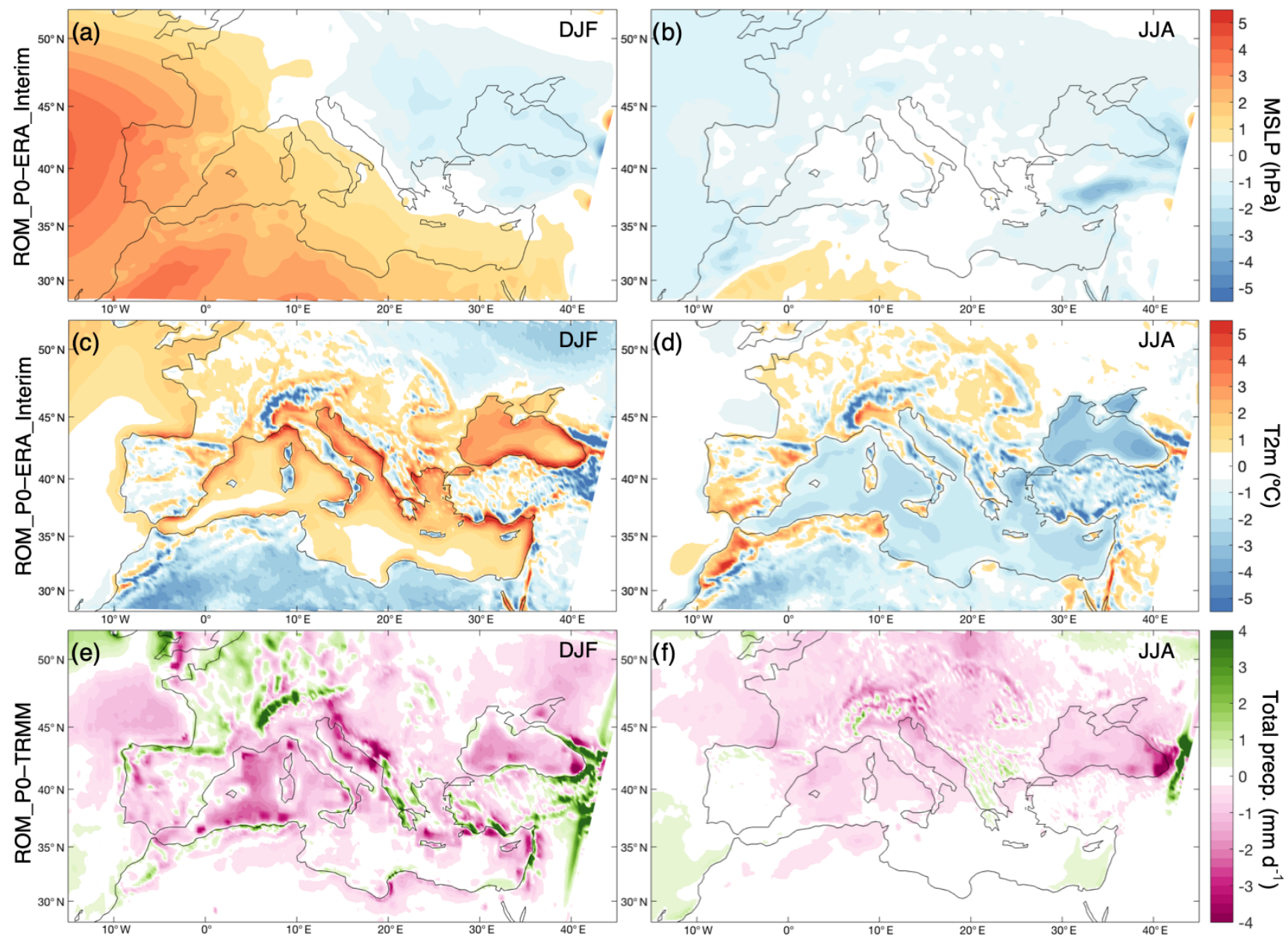

Figure 3. Differences between ROM_P0 (ERA-Interim) and TRMM for the 1980-2012 period in mean sea level pressure (MSLP, hPa) (a, b), near-surface $(2 \mathrm{~m})$ temperature $\left(\mathrm{T} 2 \mathrm{~m},{ }^{\circ} \mathrm{C}\right)(\mathbf{c}, \mathbf{d})$ and precipitation $\left(\mathrm{mm} \mathrm{d}^{-1}\right)(\mathbf{e}, \mathbf{f})$ in winter (DJF a, $\left.\mathbf{c}, \mathbf{e}\right)$ and summer $(\mathrm{JJA} \mathbf{b}, \mathbf{d}, \mathbf{f})$.

common to most of the AORCM simulations of the Mediterranean climate (see Darmaraki et al., 2019). The seasonal mean precipitation is reasonably well simulated by our coupled system throughout most of the Mediterranean basin. However, the systematic errors (up to $\pm 3.5 \mathrm{~mm} \mathrm{~d}^{-1}$ ) remain substantial over the region in terms of precipitation.

The impact of interactive atmosphere-ocean coupling in REMO is shown in Fig. 4, presenting the climatology differences between ROM_P0 and stand-alone REMO in the simulations forced by ERA-Interim for MSLP, T2m and precipitation. Over land the simulated fields are less influenced by the coupling and are largely dependent on the details of the atmospheric component. On the other hand, the impact of the coupling can be remote through the large-scale circulation (the signal which comes from the North Atlantic), and the land-sea contrasts account for the local effects. Therefore, we can expect the differences over land to be minimal, except for the regions where the large-scale circulation or the land-sea contrasts are significant. In addition, the ROM model uses an orographic gravity wave drag formulation that improves the representation of the circulation over mountainous regions in REMO.

The winter MSLP over the Atlantic is higher in the coupled run (Fig. 4a), causing an anomalous strong anticyclonic circulation that extends to land and the Mediterranean Sea west of the Balearic Islands. The influence of the large-scale MSLP anomaly cancels the effect of the local, warmer SST, which would create a low-pressure bias here (see Fig. 5, where the SST biases are represented). However, elsewhere over the Mediterranean Sea, where the ROM_P0 SST is colder (warmer) than ERA-Interim, a higher (lower) MSLP is simulated by ROM_P0. In summer (Fig. 4b), the differences in MSLP seem to be determined mainly by the colder SST in ROM_P0, which leads to higher MSLP in the model than in the reanalysis.

The changes in $\mathrm{T} 2 \mathrm{~m}$ induced by the coupling over the Mediterranean (Fig. $4 \mathrm{c}$ and d) seem to be determined mainly by the SST (see also Fig. 5) through the turbulent heat fluxes. 

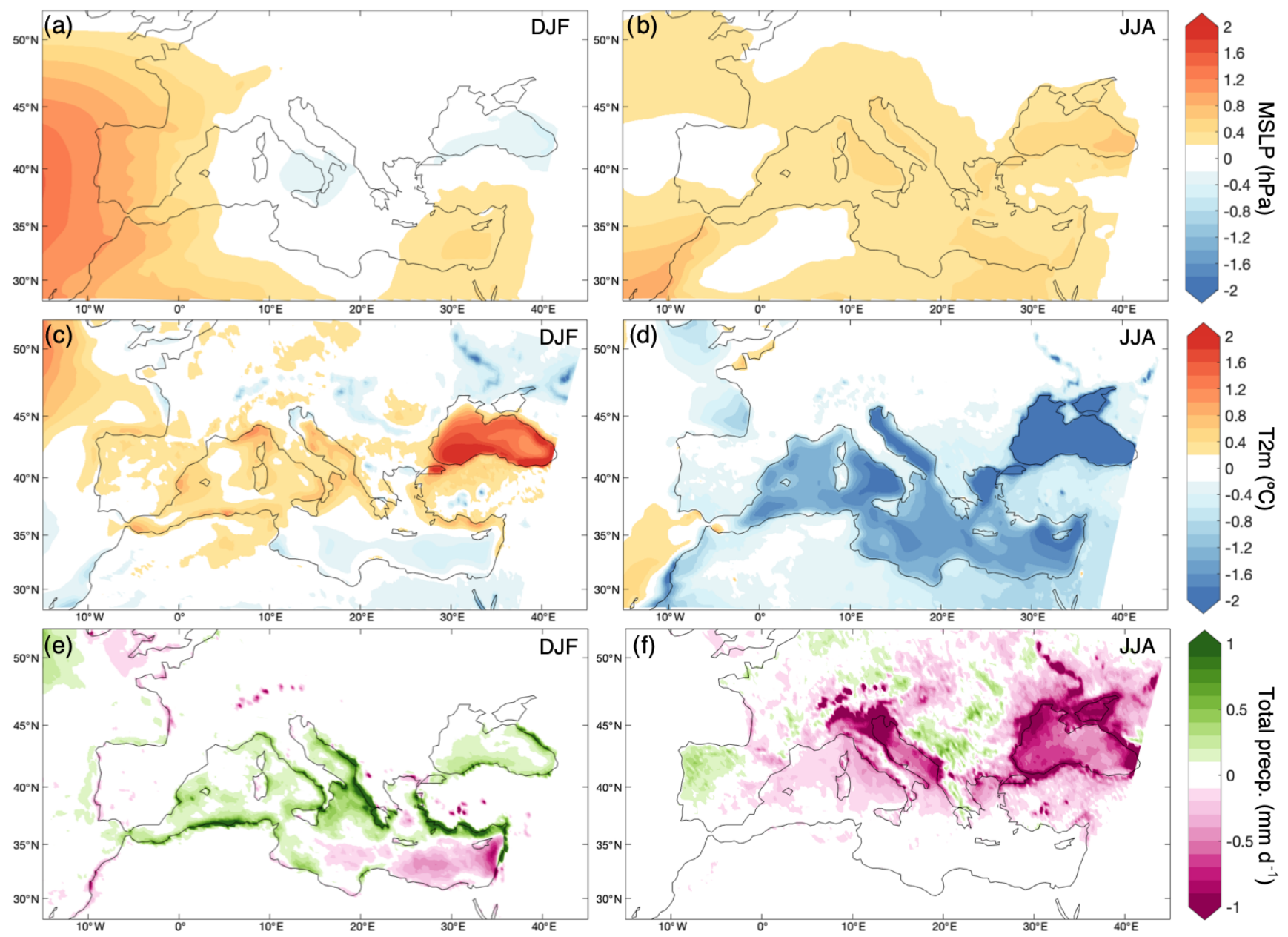

Figure 4. Differences between ROM_P0 and stand-alone REMO forced by ERA-Interim for the 1980-2012 period in mean sea level pressure $(\mathrm{MSLP}, \mathrm{hPa})(\mathbf{a}, \mathbf{b})$, near-surface $(2 \mathrm{~m})$ temperature $\left(\mathrm{T} 2 \mathrm{~m},{ }^{\circ} \mathrm{C}\right)(\mathbf{c}, \mathbf{d})$ and precipitation $\left(\mathrm{mm} \mathrm{d}^{-1}\right)(\mathbf{e}, \mathbf{f})$ in winter $(\mathrm{DJF}$ a, $\mathbf{c}, \mathbf{e})$ and summer $(\mathrm{JJA} \mathbf{b}, \mathbf{d}, \mathbf{f})$.

In both seasons, the T2m differences induced by the coupling correspond very well with the SST biases with respect to ERA-Interim. However, in winter T2m also seems to be influenced by the transport of Atlantic air carried by the too strong anticyclonic circulation simulated in the Atlantic. Over land the differences in winter $\mathrm{T} 2 \mathrm{~m}$ are mainly determined by the changes induced in large-scale circulation by the interactive SST in the Atlantic, while in summer the land-sea contrasts seem to be more significant.

The differences between the SST from ERA-Interim and the simulations by ROM_P0 are also reflected in the rainfall simulated by REMO and ROM_P0 (Fig. 4e and f) as shown by the correlation $(r=0.63)$ between winter SST and precipitation biases (including the Black Sea). In winter, the Mediterranean Sea regions where the ROM_P0 SST is warmer have higher precipitation, while colder ROM_P0 SST leads to lower precipitation. The prevalent summer cold SST bias in ROM_P0 leads to weaker precipitation throughout the Mediterranean Sea especially in the northern part.

\subsection{SST}

\subsubsection{Seasonal cycle}

The differences between ROM_P0 and observed SST climatology for winter (DJF) and summer (JJA) in the period 1980-2012 are presented in Fig. 5. The SST seasonal cycle is well represented by the model, although its amplitude is reduced over most of the Mediterranean Sea. The deviations in absolute value do not exceed $3.0^{\circ} \mathrm{C}$, although ROM_P0 shows a cold bias, which is more significant in the northern part of the eastern Mediterranean Sea especially in summer (Fig. 5).

In DJF, ROM_P0 overestimates SST over the northern Mediterranean coasts and the whole western basin, showing warm biases reaching $2.0^{\circ} \mathrm{C}$ (Fig. 5a, b and c). In summer, the cold SST bias extends over a large part of the Mediterranean domain (Fig. 5d, e and f). 

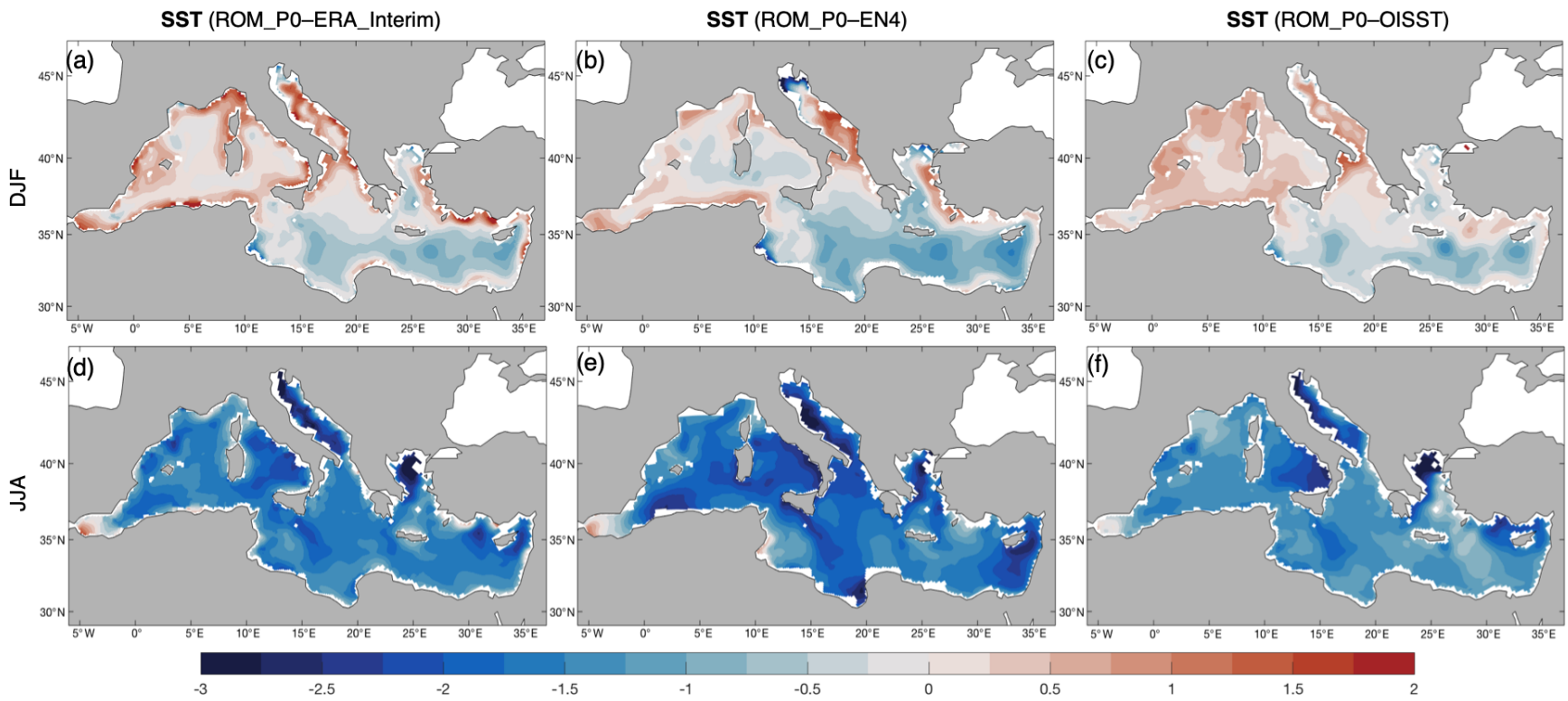

Figure 5. SST differences between ROM_P0 $\left({ }^{\circ} \mathrm{C}\right)$ and the different climatologies (ERA-Interim a, d; EN4 b, e; and OISST e, f) in winter (DJF a, b, c) and summer (JJA d, e, f).
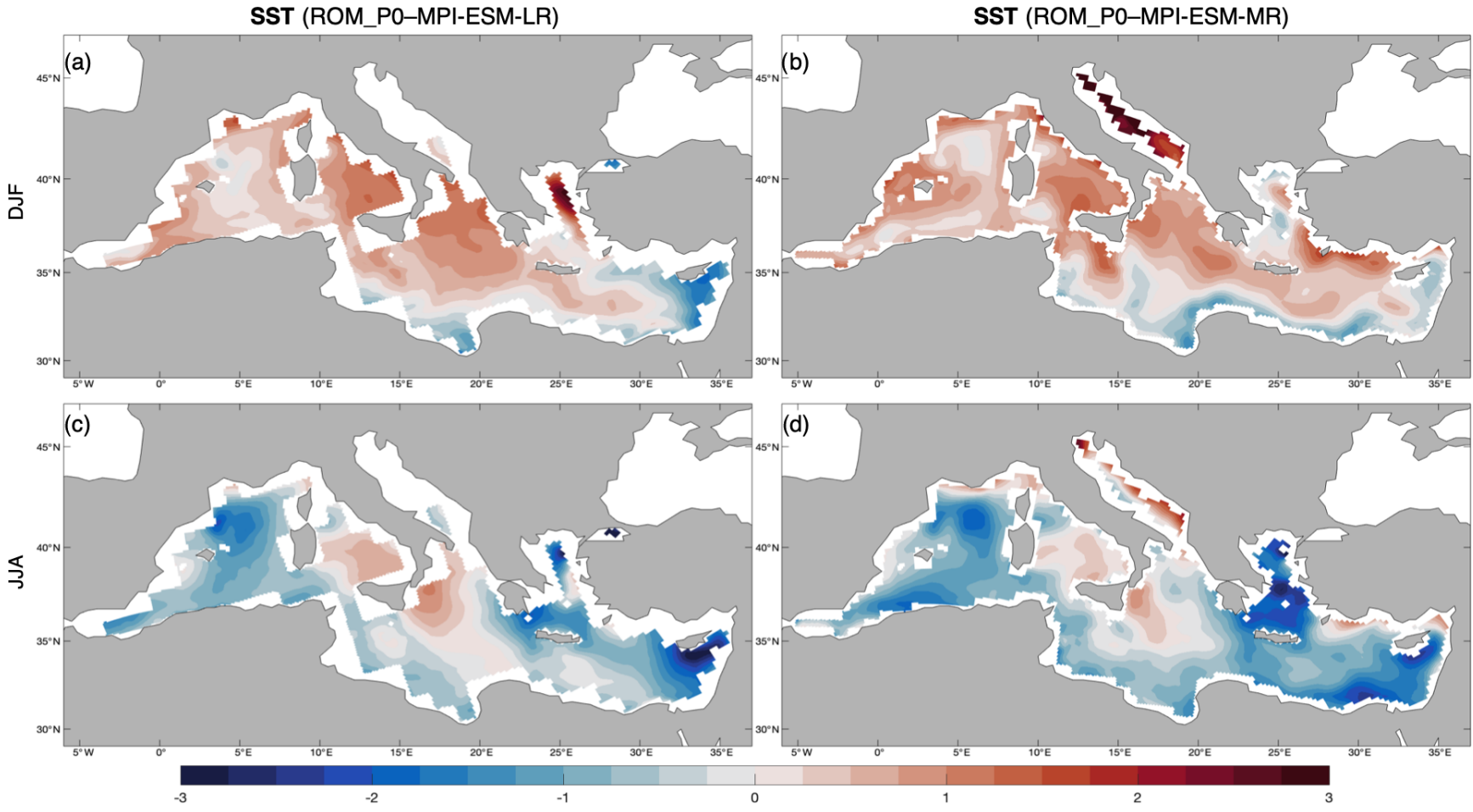

Figure 6. SST differences $\left({ }^{\circ} \mathrm{C}\right)$ between ROM_P0 and MPI-ESM-LR (a, c) and MPI-ESM-MR (b, d) in winter (DJF a, b) and summer (JJA c, d).

In order to assess the improvement that higher resolution in ROM brings to the simulation of the present Mediterranean climate (ROM_P0), comparisons with MPI-ESM-LR and MPI-ESM-MR have been done (Fig. 6).
SST seasonal cycle amplitude is smaller in ROM_P0 than in the MPI-ESMs with warmer DJF and colder JJA. The SST differences are lower than $3.0^{\circ} \mathrm{C}$ in the whole Mediterranean basin. In winter, ROM_P0 shows warmer temperatures than MPI-ESMs (MPI-ESM-LR and MPI-ESM-MR, 
Fig. 6a and b) with the exception of southeastern Mediterranean coasts where negative differences appear (approximately $\left.-1.0^{\circ} \mathrm{C}\right)$. In JJA, ROM_P0 is significantly colder over the western basin $\left(-1.5^{\circ} \mathrm{C}\right)$, southern coasts $\left(-0.5^{\circ} \mathrm{C}\right)$, and the Levantine and Aegean seas $\left(-3.0^{\circ} \mathrm{C}\right)$, while it is warmer in the Tyrrhenian, Adriatic and Ionian seas (up to $+1.0^{\circ} \mathrm{C}$; Fig. $6 \mathrm{c}$ and d).

\subsubsection{Interannual variability}

The time series of yearly mean SST averaged over the Mediterranean Sea for the period 1980-2012 (ROM_P0) shows cold biases (from 0.1 to $1.4^{\circ} \mathrm{C}$ ) compared to ERAInterim, EN4 and OISST datasets (Fig. 7), in agreement with the results displayed in Fig. 5. ERA-Interim (purple line) and OISST (red line) present a consistent behavior, and ROM_P0 shows a mean cold bias of $0.6^{\circ} \mathrm{C}$. The largest deviations are found for EN4 (yellow line) due to the lower resolution of the dataset.

ROM_P0 shows a warming trend in SST, as in the observational datasets, albeit slightly weaker (Table 3). Also, the interannual variability evident in the observed datasets is properly reproduced by ROM_P0.

A Taylor diagram (Fig. 8) was used to quantitatively evaluate ROM_P0 performance. ERA-Interim, EN4 and ROM_P0 are all well correlated $(r>0.7)$ with the observation-based analysis (OISST). The SST standard deviation of ROM_P0 $\left(0.27^{\circ} \mathrm{C}\right)$ is close to those of OISST, ERA-Interim and EN4 (0.32, 0.34 and $0.33^{\circ} \mathrm{C}$, respectively). The corresponding root mean square errors (RMSEs, red contours) show good ROM_P0 performance in simulating the interannual variability of SST, with ROM_P0 being closer to EN4 than EN4 to OISST and ERA-Interim. This could be interpreted as ROM_P0 SST lying outside but close to the uncertainty range inherent to observational gridded datasets.

\subsection{SSS}

Figure 9 shows the differences between the SSS modeled by ROM_P0 and the selected datasets averaged for DJF and JJA during the period 1980-2012. All cases show a positive bias over the western basin and Adriatic Sea and negative bias throughout the Levantine Sea and north Aegean Sea. In the northeast Adriatic Sea, by the Po Delta, the largest positive differences occur (3.0 psu), and to the north of the Aegean Sea the largest negative differences $(-3.0 \mathrm{psu})$ are found. Nevertheless, the deviations do not exceed, in absolute value, 0.5 psu in a large part of the domain (Fig. 9). Deficiencies in simulated precipitation are propagated into HD model river discharge, which is reflected in the SSS. ROM-simulated total river runoff into the Mediterranean is smaller than most of the observational estimates (e.g., Struglia et al., 2004; Wang and Polcher, 2019) and lower than other AORCM estimates (see Table 4). The influence of river runoff on SSS is highlighted by the coincidence of the largest SSS biases with lo- cations of large rivers (Po, Nile) and with the Dardanelles, whose net flow is larger than estimates (Sánchez-Gómez et al., 2011).

The ROM_P0 SSS is compared with MPI-ESM-LR and MPI-ESM-MR in Fig. 10. ROM_P0 is always saltier over the whole Mediterranean with a decreasing difference towards the southeast. In general, ROM_P0 SSS is closer to EN4 and CMEMS climatologies than any of the MPI-ESM versions due to the higher horizontal resolution of ROM_P0 in atmosphere and ocean.

\subsection{SSH and circulation}

To conclude with the analysis of the ocean component of ROM, the SSH was analyzed. The time-averaged SSH and horizontal current velocity at $31 \mathrm{~m}$ depth simulated by ROM_P0 between 1980 and 2012 are shown in Fig. 11. The $31 \mathrm{~m}$ depth level has been chosen to remove the highfrequency variability of the uppermost ocean while retaining a characteristic upper ocean circulation pattern. Furthermore, the choice of this depth makes our results more comparable with previous studies, such as L'Hévéder et al. (2013) and Sevault et al. (2014). It can be clearly seen that Atlantic surface waters enter through the Strait of Gibraltar to the western Mediterranean; after crossing the Alboran Sea, the Atlantic Water flows along the African coast. At the Strait of Sicily, part of the Atlantic Water deflects northward along the coast of the Tyrrhenian Sea while the rest continues flowing to the eastern basin. ROM_P0 reproduces quite clearly the well-known deep water formation sites, especially in the Gulf of Lion, the southern Adriatic Sea and the Levantine Sea (near the islands of Crete and Rhodes), identified by the presence of three cyclonic gyres. These cyclonic gyres concur with negative SSH values, which highlight the sinking of surface waters. The mean SSH closely reproduces the well-established and steady basin- and subbasin-scale circulation pattern (e.g., Bergamasco and Malanotte-Rizzoli, 2010). However, mesoscale structures of circulation, such as the Mersa Matruh and Shikmona anticyclonic gyres, escape the model's horizontal resolution in the eastern basin (ca. $25 \mathrm{~km}$ ).

A first-order comparison of the model's SSH to the AVISO sea level anomaly (SLA) (SSALTO/DUACS, 2013) can be done by adding only the thermosteric contribution (as a constant resulting from the average over the whole basin) to the dynamic SSH of the model (Sevault et al., 2014). Figure 12 shows the yearly mean and the seasonal cycle of ROM_P0 $\mathrm{SSH}$ compared to altimetric data. The modeled SSH shows lower values than those observed (Fig. 12a); however, it represents the behavior of the AVISO SLA time series well. The amplitude of the mean seasonal cycle is $12 \mathrm{~cm}$ for the simulation and $14.5 \mathrm{~cm}$ for AVISO (Fig. 12b). Therefore, the model is able to reproduce a realistic interannual variability and seasonal cycle. 
Table 3. Trend computed from yearly means during 1980-2012 by the different analyses of the Mediterranean Sea.

\begin{tabular}{rrrrrrr}
\hline & ROM_P0 & OISST & ERA-Interim & EN4 & MPI-ESM-LR & MPI-ESM-MR \\
\hline${ }^{\circ} \mathrm{C} \mathrm{yr}^{-1}$ & +0.016 & +0.027 & +0.029 & +0.022 & +0.028 & +0.020 \\
\hline
\end{tabular}

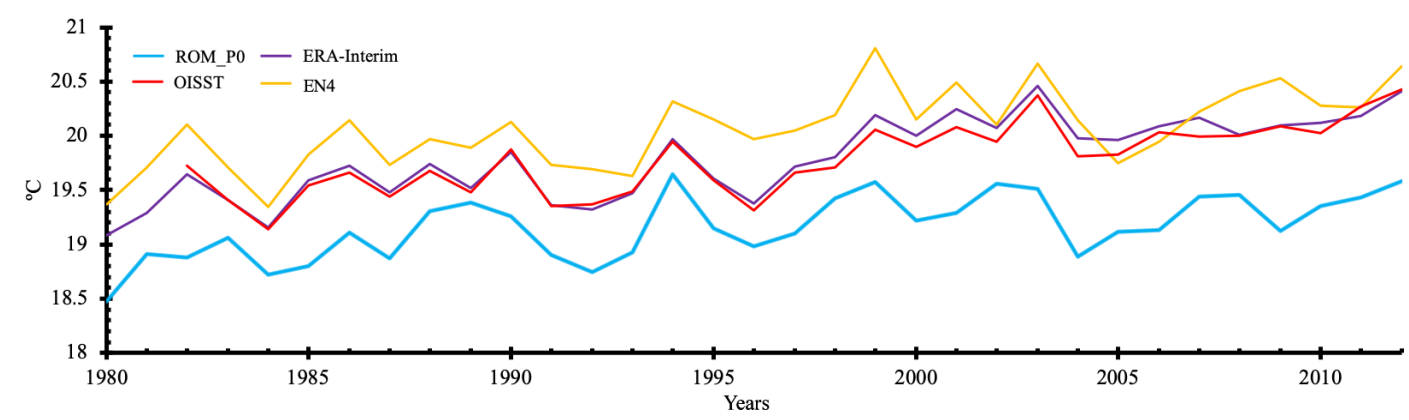

Figure 7. Time series of yearly mean (1980-2012) SSTs $\left({ }^{\circ} \mathrm{C}\right)$ averaged over the Mediterranean basin. ROM_P0 (blue), OISST (red), ERAInterim (purple) and EN4 (yellow).

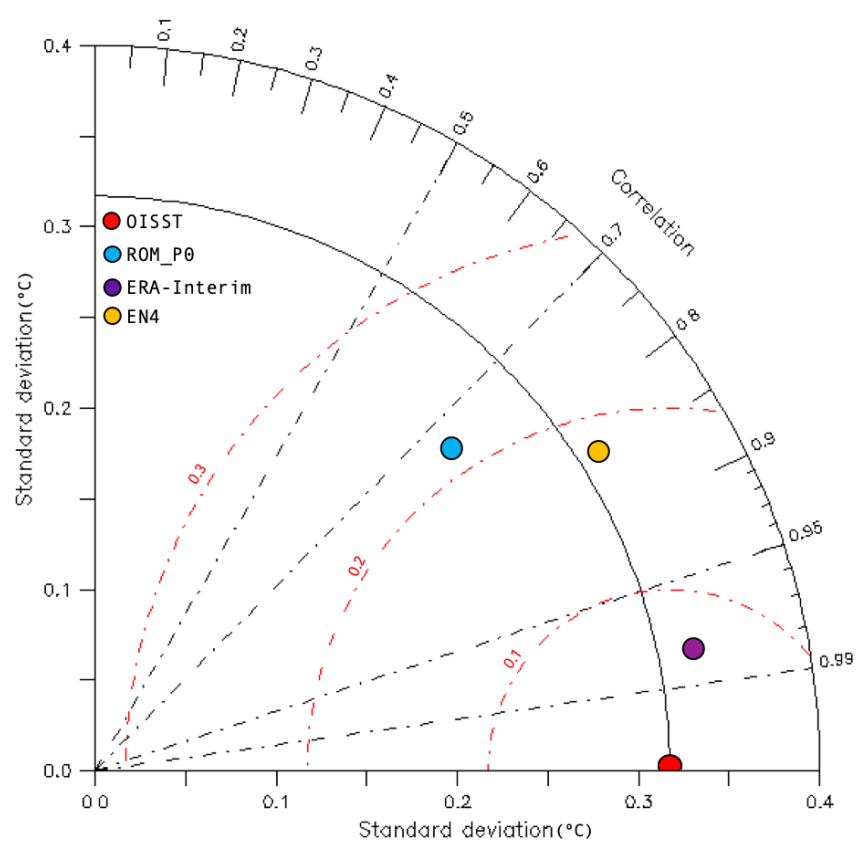

Figure 8. Taylor diagram for Mediterranean SSTs during the 19822012 period. The diagram summarizes the relationship between standard deviation $\left({ }^{\circ} \mathrm{C}\right)$, correlation $(r)$ and RMSE (red lines, ${ }^{\circ} \mathrm{C}$ ) for all datasets. The gridded OISST was employed as reference.

Finally, a mass balance was carried out to estimate the net transport of water throughout the Strait of Gibraltar and the Dardanelles in order to compare the water flux modeled by ROM with the observations. Table 4 gives the water budget of ROM_P0 averaged over the period 1980-2012. The water loss by evaporation $(E)$ is greater than the gain by precipitation $(P)$ and river runoff $(R)$, generating a deficit of $0.053 \mathrm{~Sv}$ in the basin. However, this deficit is partially compensated for by the net water inflow through the Strait of Gibraltar $(0.030 \mathrm{~Sv})$ and the Dardanelles, where the inflow $(0.132 \mathrm{~Sv})$ exceeds the outflow $(0.109 \mathrm{~Sv})$. The ROM_P0 water budget $(E-(P+R))$ is $0.007 \mathrm{~Sv}$ lower compared to the RCSM4 model (Sevault et al., 2014), although a significant part of the difference is due to difference in river runoff.

\subsection{Projections under RCP8.5 scenario}

Figure 13 shows the mean SST and SSS fields for the present climate (1976-2005, ROM_P1) together with the differences with respect to future projections under the RCP8.5 scenario (ROM_P2-ROM_P1). At basin scale, the SST (ROM_P1; Fig. 13a) increases from northwest to southeast over the Mediterranean Sea with the western Mediterranean colder than the eastern, especially in the Gulf of Lion and in the northern Adriatic Sea where the SST minima are located (Fig. 13a). The warmest area is found along the Levantine Sea coast. The averaged Mediterranean SST is $18.6^{\circ} \mathrm{C}$, and, by the end of the 21 st century under the RCP 8.5 scenario, it is expected to have a mean increase of $2.7^{\circ} \mathrm{C}$ with a projected warming ranging from a maximum of $3.8^{\circ} \mathrm{C}$ in the Aegean Sea to a minimum of $0.9^{\circ} \mathrm{C}$ in the Alboran Sea (Fig. 13b).

To verify that the simulated warming trend remains stable and is not affected by the strong ROM SST bias, comparisons for DJF and JJA have been performed separately (see Supplement). The comparable warming is appreciable in both seasons with a larger SST in the eastern basin. The influence of the seasonal cycle is limited to the location of the minima and maxima.

As shown in Fig. 13c, the surface of the eastern Mediterranean is saltier than the western Mediterranean, reaching 39.0 psu at the Levantine Sea. The western basin presents lower salinities $(<38.3 \mathrm{psu})$ influenced by the inflow of less saline Atlantic Water through the Strait of Gibraltar 
Table 4. Water balance and exchange flows for the Mediterranean Sea according to ROM_P0, RCSM4 and observation-based estimates. All results are presented in sverdrups $(\mathrm{Sv})$.

\begin{tabular}{lcrl}
\hline Parameters & 1980-2012 mean ROM_P0 & RCSM4 (Sevault et al., 2014) & \multicolumn{1}{l}{ Estimates } \\
\hline Evaporation & 0.093 & 0.110 & $0.086-0.089$ (Sánchez-Gómez et al., 2011) \\
Precipitation & 0.034 & 0.040 & $0.020-0.047$ (Sánchez-Gómez et al., 2011) \\
Runoff & 0.006 & 0.010 & - \\
$E-P$ & 0.059 & 0.070 & $0.039-0.069$ (Sánchez-Gómez et al., 2011) \\
$E-(P+R)$ & 0.053 & 0.060 & - \\
Gibraltar in & 0.554 & 0.850 & 0.81 (Soto-Navarro et al., 2014) \\
Gibraltar out & 0.524 & 0.800 & 0.78 (Soto-Navarro et al., 2014) \\
Gibraltar net & 0.030 & 0.050 & $0.04-0.10$ (Soto-Navarro et al., 2014) \\
Dardanelles in & 0.132 & - & - \\
Dardanelles out & 0.109 & - & - \\
Dardanelles net & 0.023 & 0.007 & $0.008-0.01$ (Sánchez-Gómez et al., 2011) \\
\hline
\end{tabular}

Table 5. Resolution of the different models used in this study to discuss ROM.

\begin{tabular}{llll}
\hline Model & Model configuration & Atmosphere-ocean resolution & References \\
\hline MGME ensemble & Global & $1-4^{\circ} /-$ & Giorgi and Lionello (2018) \\
PROTHEUS & AORCM & $30 \mathrm{~km} / 13 \mathrm{~km}$ & Artale et al. (2010) \\
LMDz-NEMO-Med & AORCM & $30 \mathrm{~km} / 9-12 \mathrm{~km}$ & L'Hévéder et al. (2013) \\
WRF RCM & RCM & $50 \mathrm{~km} /-$ & Di Luca et al. (2014) \\
CNRM-RCSM4 & AORCM & $50 \mathrm{~km} / 9-12 \mathrm{~km}$ & Sevault et al. (2014) \\
RCM11 & RCM & $12 \mathrm{~km} /-$ & Fantini et al. (2018) \\
RCM44 & & $50 \mathrm{~km} /-$ & \\
\hline
\end{tabular}

(36.6 psu) along the African coasts up to the Ionian Sea. Another source of freshwater is located at the Dardanelles strait where the Black Sea outflow has salinities lower than 35 psu. The averaged Mediterranean SSS is $38.0 \mathrm{psu}$, while under the RCP8.5 projection it will experience a mean increase of $0.2 \mathrm{psu}$. The differences between the mean SSS projection and the present climate show a dipolar structure through the Mediterranean Sea (Fig. 13d). Under the RCP8.5 scenario, the western Mediterranean is expected to increase slightly in fresh water (from -0.5 to $-1.0 \mathrm{psu}$ ), while the eastern will become saltier. It is precisely in the north of the Aegean Sea where the largest SSS increases (4.0 psu) are found.

MPI-ESM-LR and MPI-ESM-MR projections under the RCP8.5 scenario by the end of the 21 st century are slightly warmer than those of ROM over most of the Mediterranean Sea. Namely, the projected mean SST increases are 2.8 and $2.9^{\circ} \mathrm{C}$ for MPI-ESM-LR and MPI-ESM-MR, respectively (Table 6). Compared to ROM, both MPI-ESMs show a tendency to shift the largest warming to the west, more prominently in MPI-ESM-MR, with a local minimum extending over the eastern basin (Fig. 14a and b). It is also remarkable that MPI-ESM-MR identifies the maximum warming in the Adriatic Sea and the northern Aegean Sea in the Dardanelles water outlet (Fig. 14b).

The mean SSS increase projected by ROM for the 2070-2099 period compared to 1976-2005 under RCP8.5
Table 6. Mediterranean Sea average spatial changes in SST and SSS by the end of the 21 st century as compared with the present climate.

\begin{tabular}{llrr}
\hline & Scenario & $\begin{array}{r}\Delta \text { SST } \\
\left({ }^{\circ} \mathrm{C}\right)\end{array}$ & $\begin{array}{r}\Delta \text { SSS } \\
(\mathrm{psu})\end{array}$ \\
\hline ROM & RCP8.5 & +2.7 & +0.2 \\
MPI-ESM-LR & RCP8.5 & +2.8 & +0.1 \\
MPI-ESM-MR & RCP8.5 & +2.9 & +0.1 \\
Thorpe and Bigg (2000) & 2 XCO 2 & +4 & - \\
Somot et al. (2006) & A2 & +2.50 & +0.33 \\
Somot et al. (2008) & A2 & +2.60 & +0.43 \\
Shaltout and Omstedt (2014) & RCP2.6 & +0.5 & - \\
(Shaltout and Omstedt (2014)) & RCP4.5 & +1.15 & - \\
(Shaltout and Omstedt (2014)) & RCP6.0 & +1.42 & - \\
(Shaltout and Omstedt (2014)) & RCP8.5 & +2.6 & - \\
Adloff et al. (2015) & A2 & +2.53 & +0.48 \\
(Adloff et al. (2015)) & A2-F & +2.97 & +0.69 \\
(Adloff et al. (2015)) & A2-ARF & +2.97 & +0.89 \\
(Adloff et al. (2015)) & B1-ARF & +1.73 & +0.70 \\
Darmaraki et al. (2019) & RCP8.5 & +3.1 & - \\
\hline
\end{tabular}

(ROM_P2-ROM_P1) is larger than for any of the MPI-ESMs (Table 4), but the salinity change dipolar spatial pattern is roughly the same in all three projections (Figs. 13d and 14c and d). 

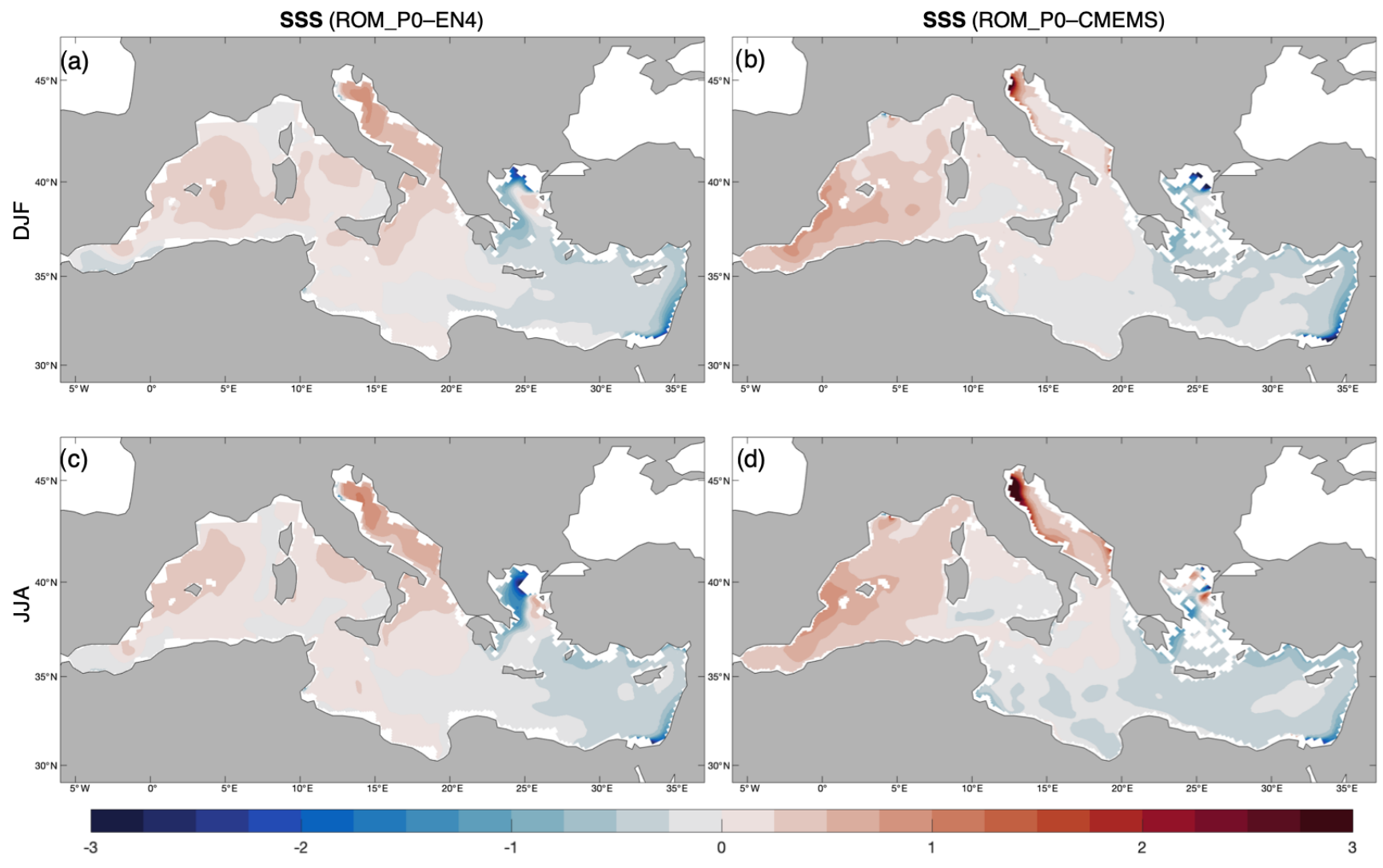

Figure 9. SSS (psu) differences between the ROM_P0 climatologies (EN4 a, c and CMEMS d, e) in winter (DJF a, b) and summer (JJA c, d).

Figure 15 shows the mean temporal evolution of temperature and salinity anomalies in the water column over the western and eastern Mediterranean throughout the 21st century according to the ROM projection for the RCP8.5 scenario. To calculate these anomalies in a given region, we first average horizontally, over the area indicated in the Fig. 15 insets, the temperature and salinity in each MPIOM level for the present time period (1976-2005) and the RCP8.5 projection period (2006-2099). The anomalies are defined as the difference between the time series for the RCP8.5 scenario (2006-2099) and the time mean for the present climate period (ROM_P1). The Mediterranean Sea shows a gradual increase in its temperature throughout the entire water column (Fig. 15a and c), which is most pronounced in surface layers. The warming accelerates in the second half of the century, with a very clear warming signal in the upper $500 \mathrm{~m}$ of the eastern Mediterranean. This warming signal propagates at intermediate depths (200-500 m, corresponding to the equilibrium depth of Levantine Intermediate Water (LIW); e.g., Menna and Poulain, 2010) into the western basin. By the end of the 21 st century, the eastern basin is expected to experience a surface temperature increase of up to $3.8^{\circ} \mathrm{C}$ and the western up to $3{ }^{\circ} \mathrm{C}$. At $1000 \mathrm{~m}$ depth the water temperature will increase by $0.6^{\circ} \mathrm{C}$ for both basins, which is a very notable warming at these depths.

The time evolution of mean salinity anomalies displays different patterns throughout the Mediterranean Sea. During the 21 st century, the upper layer $(0-100 \mathrm{~m})$ of the western Mediterranean is projected to freshen $(-0.5 \mathrm{psu})$ while the deeper layers tend to get saltier by up to 0.5 psu. However, the eastern Mediterranean will increase its salinity by up to $0.5 \mathrm{psu}$ in the entire water column. It is interesting to note that both temperature and salinity increases in the western Mediterranean at intermediate depths are delayed compared to the eastern Mediterranean.

\section{Discussion}

AORCMs are capable of improving the simulation of the climate system by the driving model through dynamical downscaling from general circulation models (GCMs) (e.g., Li et al., 2012; Sein et al., 2015). The regionalization implemented in the ROM model provides higher horizontal resolution, allowing the representation of local-scale and mesoscale processes that are not detectable by MPI-ESMs. The higher horizontal resolution also allows ROM_P0 to resolve explic- 

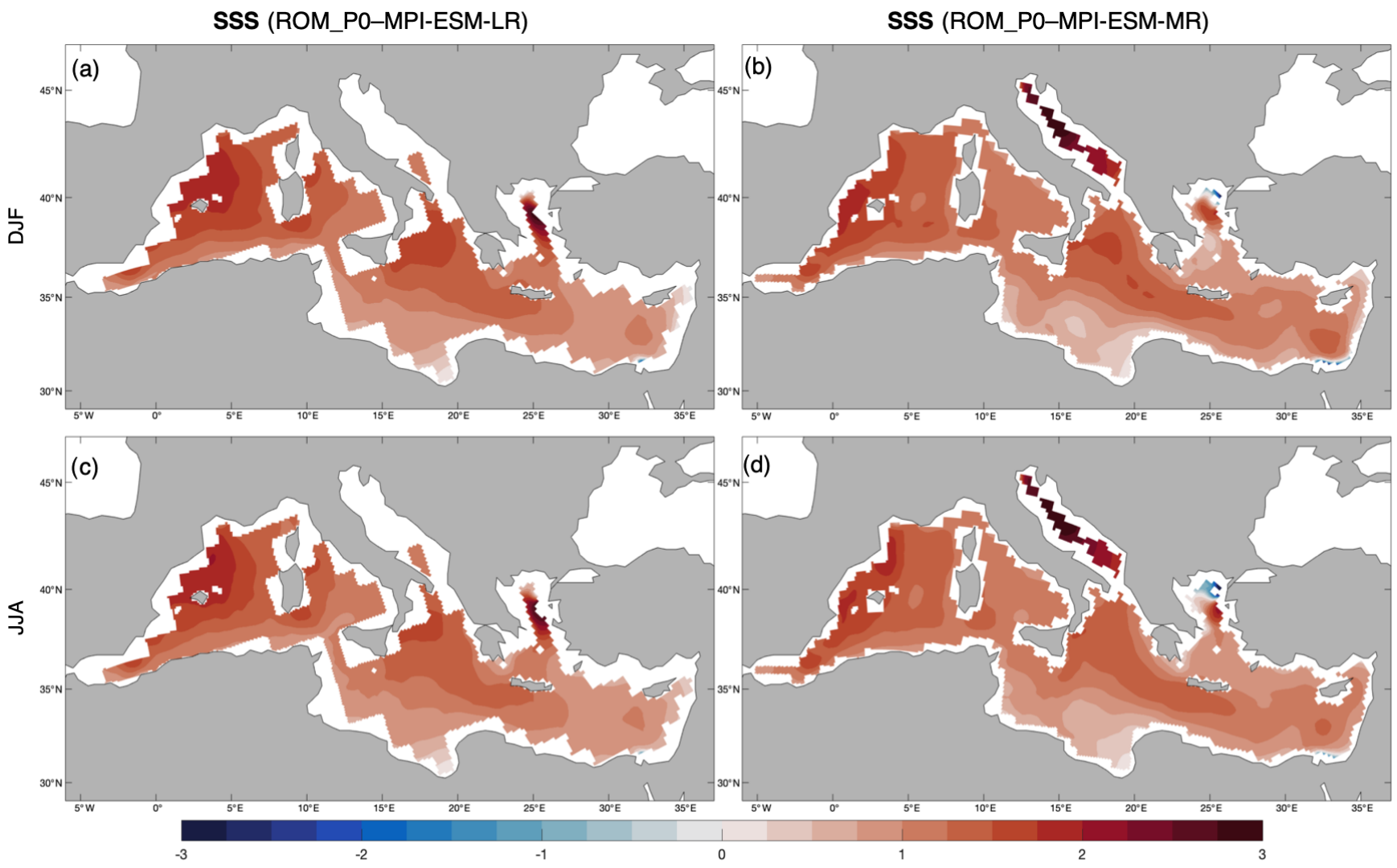

Figure 10. SSS (psu) differences between the ROM_P0 and MPI-ESM-LR (a, c) and MPI-ESM-MR (b, d) in winter (DJF a, b) and summer $(\mathrm{JJA} \mathbf{c}, \mathbf{d})$.

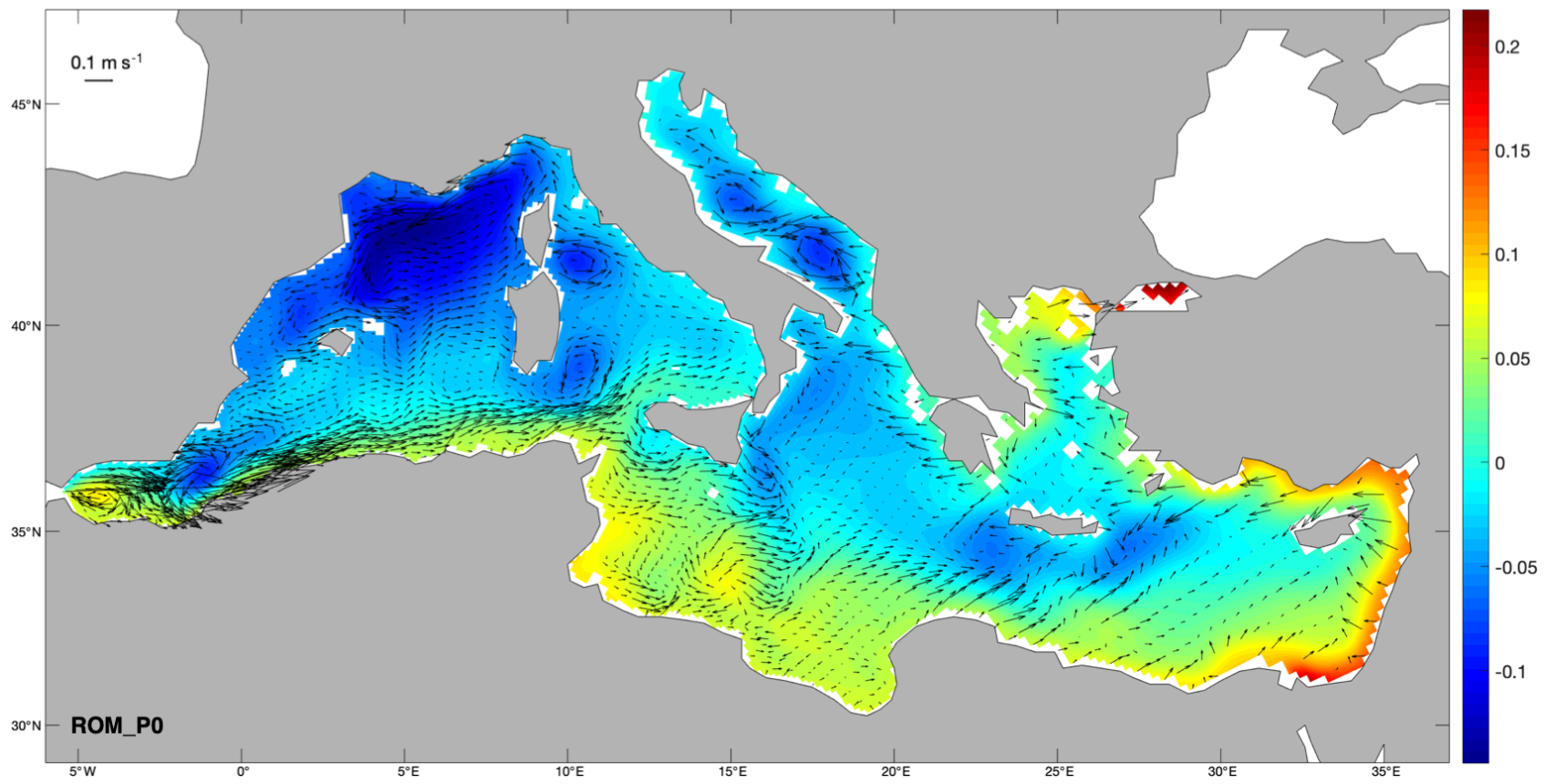

Figure 11. Mean (1980-2012) ROM_P0 SSH (m) and horizontal current velocity at $31 \mathrm{~m}$ depth (vectors, in $\mathrm{m} \mathrm{s}^{-1}$ ). Only every sixth vector is plotted. 

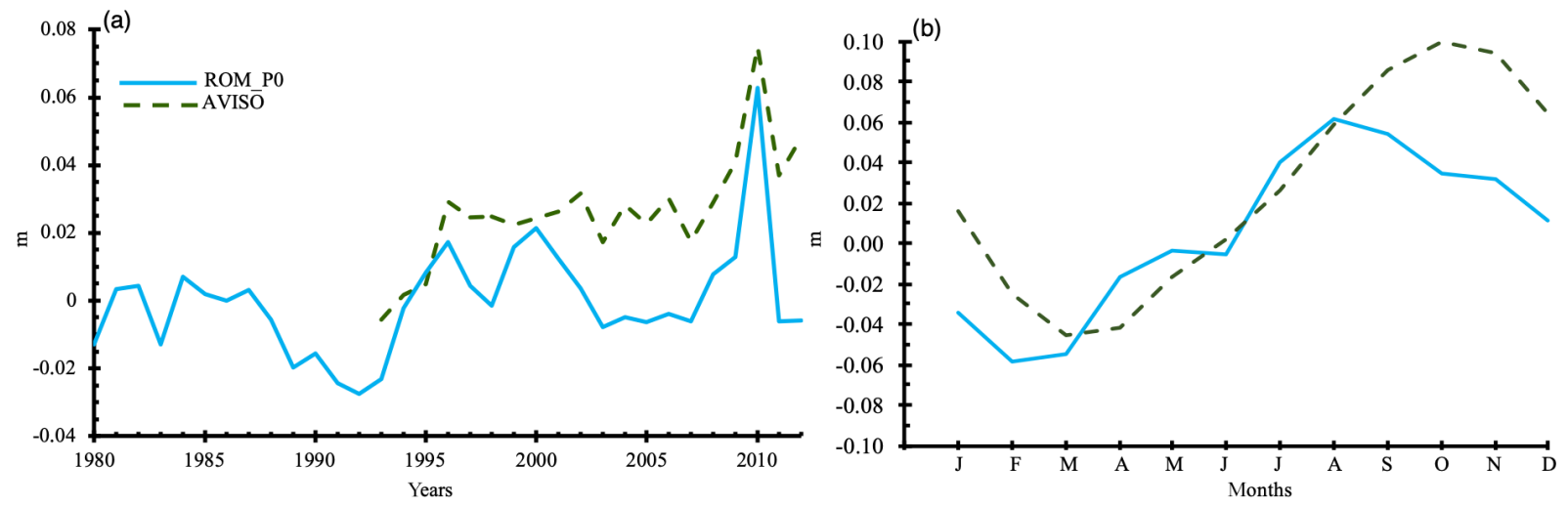

Figure 12. Time series of mean (1980-2012) sea level anomalies averaged over the Mediterranean basin (a, in m). For ROM_P0 (blue), the dynamic SSH is added to the thermosteric term. Model data are compared to observations (dashed green, AVISO). ROM_P0 seasonal cycle data are compared to AVISO data (b).
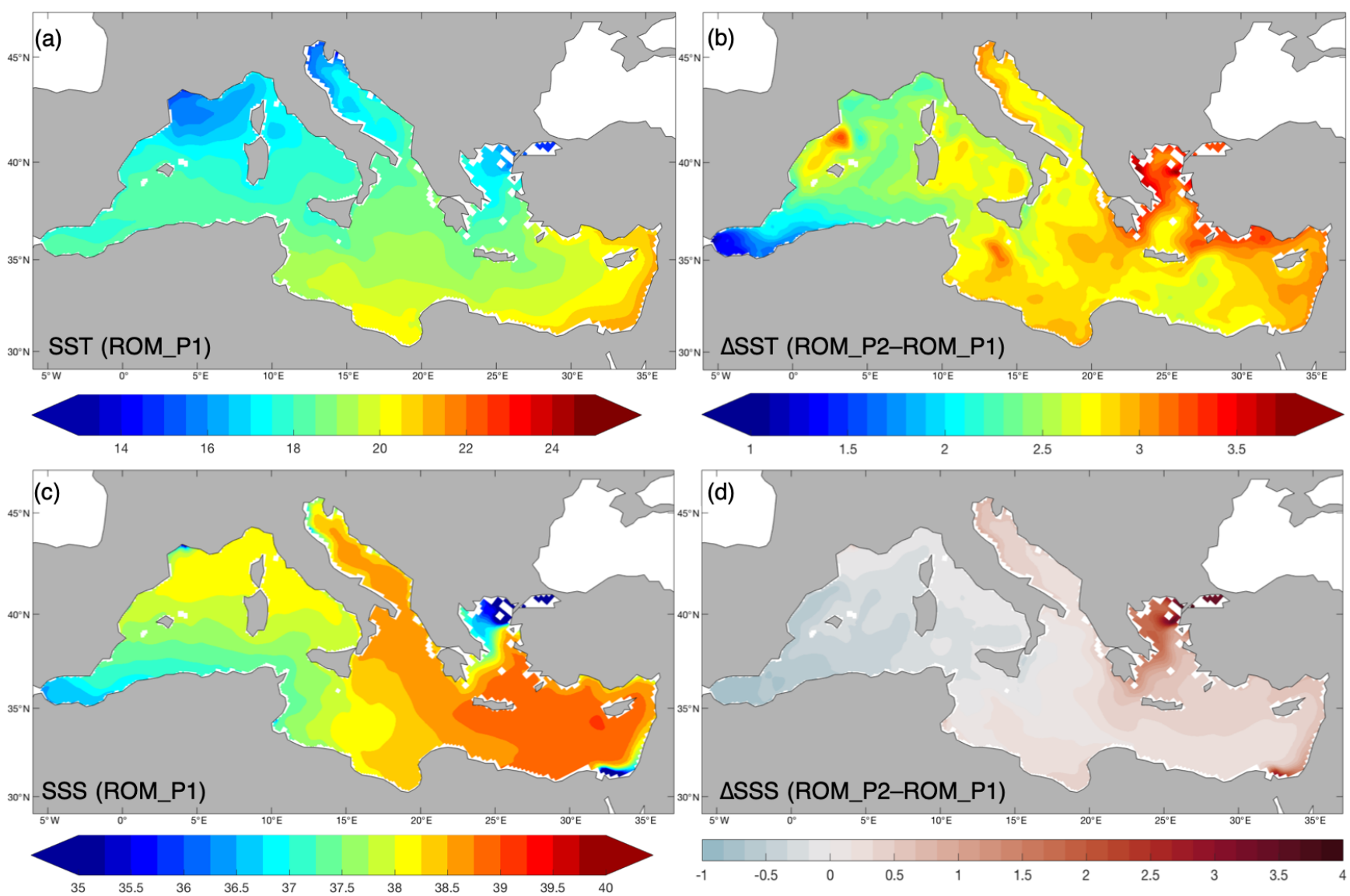

Figure 13. Mean SST (a, in $\left.{ }^{\circ} \mathrm{C}\right)$ and SSS (c, in psu), averaged over the 1976-2005 period (ROM_P1). Differences between mean SST (b, in ${ }^{\circ}$ C) and SSS (d, in psu) in RCP8.5 projection (2070-2099, ROM_P2) and present climate (1976-2005, ROM_P1).

itly the water exchange through a more realistic Straight of Gibraltar and Dardanelles, taking into account the largescale feedbacks between the Mediterranean and the adjacent basins (North Atlantic and Black Sea). Compared to other state-of-the-art regional climate models, ROM introduces the novel approach of implementing a global ocean model with high horizontal resolution at regional scales. This allows us to obtain information of the global ocean maintaining the high spatial resolution in the coupling area. An important disadvantage of the proposed model, described previously in Sein et al. (2014), is that the bias and internal variability generated from the global domain can influence the results in the 

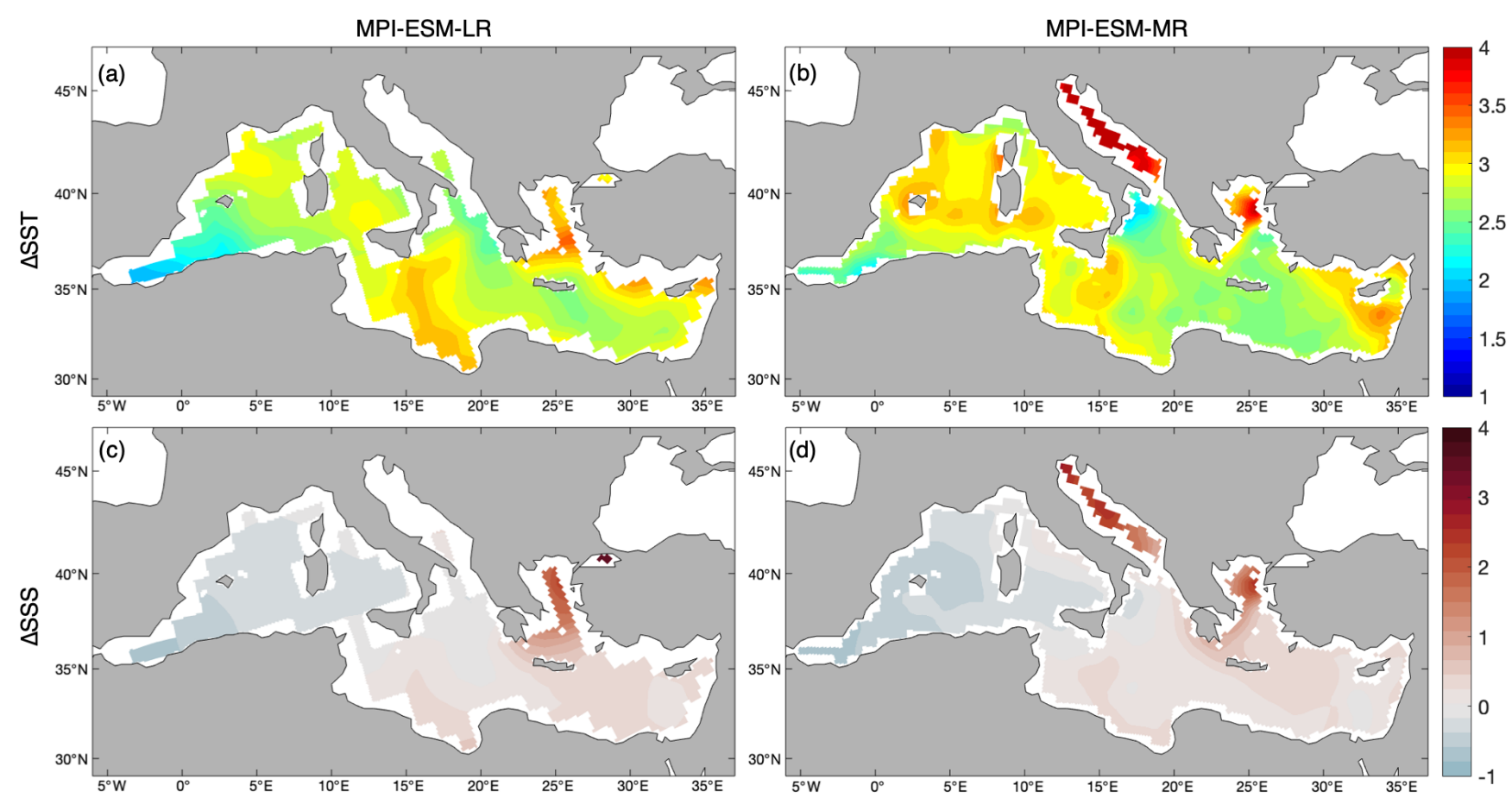

Figure 14. $\operatorname{SST}\left(\mathbf{a}, \mathbf{b}\right.$, in $\left.{ }^{\circ} \mathrm{C}\right)$ and SSS (c, $\mathbf{d}$, in psu). MPI-ESM-LR (a, c) and MPI-ESM-MR (b, d) anomaly fields estimated as the difference between the average of the RCP8.5 projection (2070-2099) and present climate (1976-2005).

coupled domain, making it difficult to separate the sources of bias.

ROM is able to reproduce the main characteristics of the climate of the Mediterranean Sea. The biases of the main atmospheric and oceanic parameters are in the range shown by other state-of-the-art regional models (L'Hévéder et al., 2013; Sevault et al., 2014; Akhtar et al., 2018; Darmaraki et al., 2019).

The seasonal MSLP was validated against ERA-Interim, showing biases smaller than $\pm 3 \mathrm{hPa}$ over most the domain for DJF and JJA, a performance similar to other models (see, e.g., Giorgi and Lionello, 2008; Velikou et al., 2019). Positive MSLP biases over a large extent of the domain during DJF (Fig. 3a) could generate anticyclonic conditions which lead to a greater stability and lower storm generation, while in JJA (Fig. 3b) the biases are generally much lower. With respect to the seasonal cycle of near-surface atmospheric parameters such as near-surface $(2 \mathrm{~m})$ temperature $(\mathrm{T} 2 \mathrm{~m})$ and precipitation, the LMDz-NEMO-Med coupled model, composed of LMDz4-regional as the atmospheric component and of NEMOMED8 as the oceanic component (L'Hévéder et al., 2013) (Table 5), gives a bias (ranging from -4 to $+4{ }^{\circ} \mathrm{C}$ and -2 to $+3 \mathrm{~mm} \mathrm{~d}^{-1}$, respectively) which is comparable to the ROM_P0 estimates (Fig. 3c, d, e and f). Similar to most of the Mediterranean regional models, ROM_P0 shows higher than observed rainfall over areas with pronounced topography such as the Alps (Artale et al., 2010; L'Hévéder et al., 2013; Di Luca et al., 2014) (Table 5). More recently, Fan- tini et al. (2018) also reported a similar bias $\left( \pm 3 \mathrm{~mm} \mathrm{~d}^{-1}\right)$ in an ensemble of regionally coupled models forced by ERAInterim. Panthou et al. (2018) observed that for heavy precipitation increasing resolution increases the wet biases when comparing simulations that share the same set of parameters. We agree with the final consideration of Fantini et al. (2018); the authors propose that in order to assess the performance of the RCMs with ever increasing resolution in simulating precipitation, we urgently need observations with high temporal and spatial resolutions.

The comparison of the ROM_P0 with the stand-alone REMO shows that the changes in SST generated by the coupling in the Atlantic Ocean influence the simulated Mediterranean climate, causing a spurious anticyclonic circulation in winter which impacts the surface temperature in the western Mediterranean. In summer, the modeled SST is significantly colder than observations, leading to colder $\mathrm{T} 2 \mathrm{~m}$ and less precipitation over the basin as the colder SST reduces the evaporation. In order to explicitly assess the role of the regional coupling on the simulated temperature, salinity and sea level, the results presented here will be compared with those from an uncoupled MPIOM simulation, which is in progress.

Regarding SST, ROM_P0 shows biases within $3.0^{\circ} \mathrm{C}$, correlation coefficients above 0.7 and RMSE below $0.25^{\circ} \mathrm{C}$ when compared to ERA-Interim, EN4 and OISST datasets. ROM_P0 presents cold biases along the eastern Mediterranean that become stronger and extend to the whole basin in summer months. The summer biases are common to most 

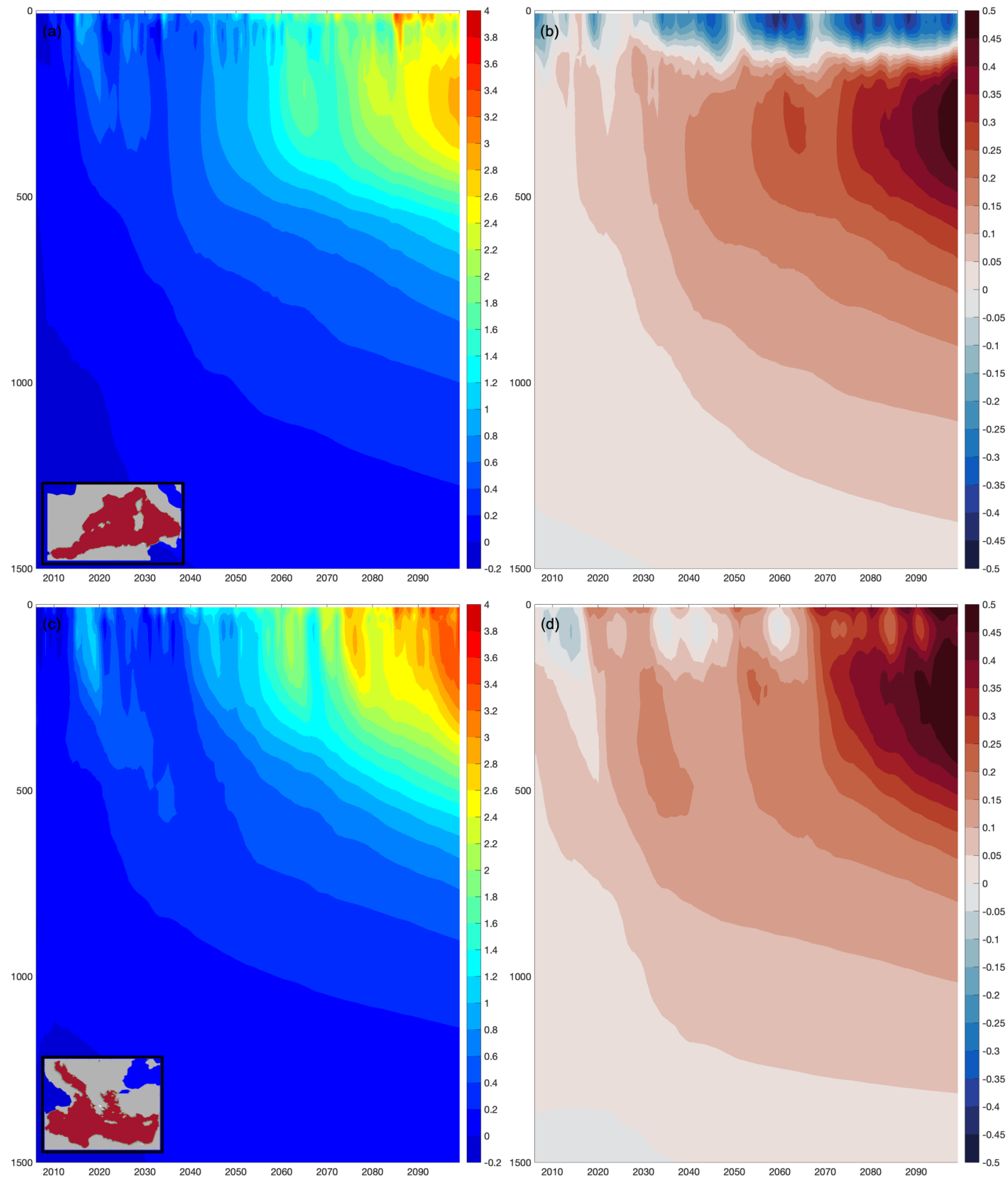

Figure 15. Temporal evolution of mean temperature $\left(\mathbf{a}, \mathbf{c}\right.$, in $\left.{ }^{\circ} \mathrm{C}\right)$ and salinity $(\mathbf{b}, \mathbf{d}$, in psu) throughout the 21 st century in the western $(\mathbf{a}, \mathbf{b})$ and eastern (c, d) Mediterranean.

of the Mediterranean regionally coupled simulations (see, for instance, Dubois et al., 2012; Li et al., 2012; Sevault et al., 2014). Akhtar et al. (2018) studied the impact of resolution and coupling in modeling the climate of the Mediterranean Sea and concluded that coupling generates a negative bias in SST. Most recently, Darmaraki et al. (2019) assessed an ensemble of 17 simulations from six models, in which our ROM-coupled system was included. Their results showed an averaged cold bias ranging from $\left(-0.29\right.$ to $\left.-1.01^{\circ} \mathrm{C}\right)$ when regional models are compared to satellite data. This cold bias is very evident in Fig. 7, where ROM_P0 shows averaged Mediterranean SSTs that reproduce the trend and interannual variability but are systematically colder than reference climatologies during the period 1980-2012, a common trait with other RCSMs (Sevault et al., 2014; Ruti et al., 2015). Macias et al. (2018) showed that a simple, spatially uniform bias cor- 

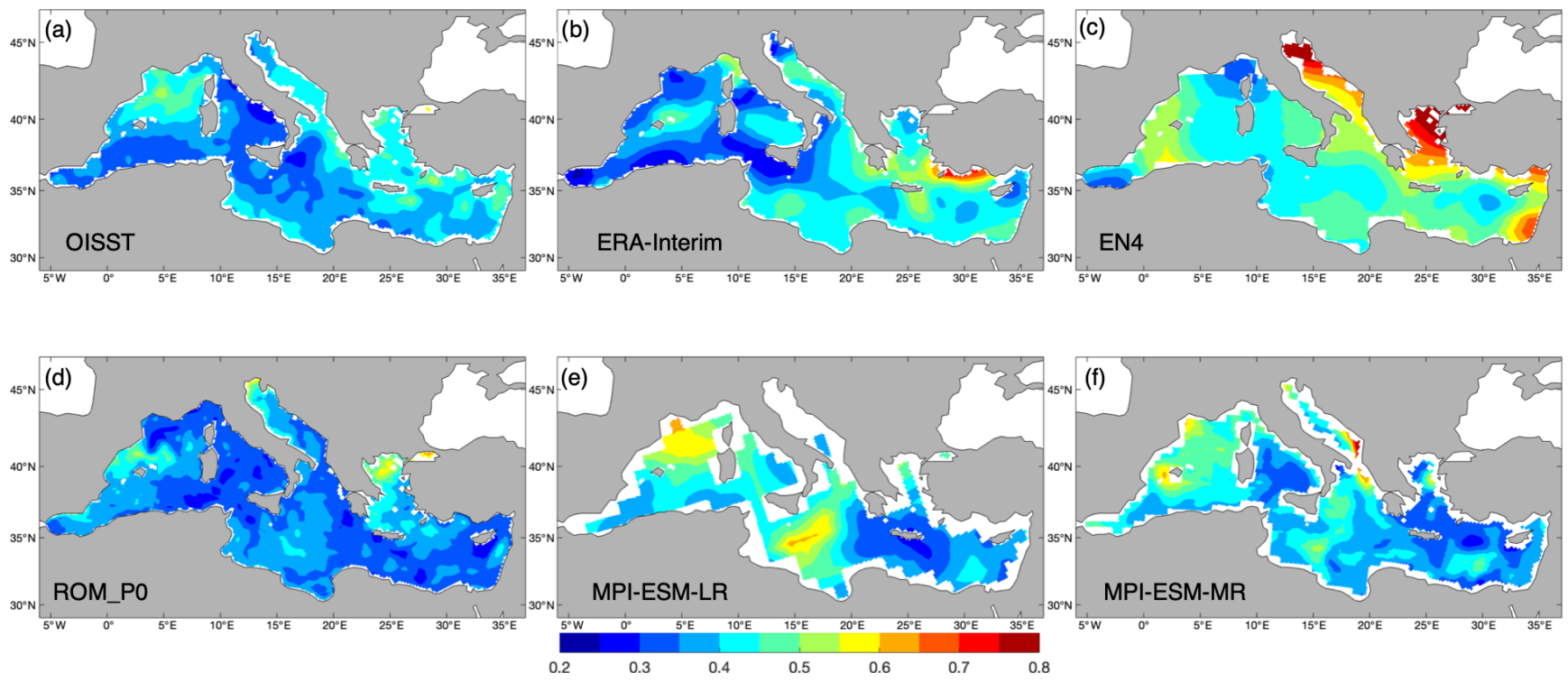

Figure 16. Yearly mean SST standard deviations (in ${ }^{\circ} \mathrm{C}$ ) for the 1982-2012 period: OISST (a), ERA-Interim (b), EN4 (c), ROM_P0 (d), MPI-ESM-LR (e) and MPI-ESM-MR (f).

rection improves the simulated surface oceanic conditions of the Mediterranean basin when forcing an oceanic model with atmospheric data from RCM realizations. The causes of the cold summer SST biases could be related either to a deficit of solar radiation by the atmospheric model or to shortcomings in the simulation of certain processes in the ocean model, such as vertical mixing or turbidity. It is difficult to attribute the bias to a single cause without considering the multiplicity and complexity of all the involved conditions; therefore, this topic deserves a separate and focused study. However, a preliminary sensitivity analysis (not shown) changing the optical properties of the water (changing from model standard Jerlov Ia to Jerlov II) clearly indicates that the related turbidity increase is responsible for a larger absorption of downward shortwave radiation in the upper layer, leading to a warmer SST. This also would explain why colder SST biases are in summer when the impact of biologically induced redistribution of heat in the water column is larger. Switching HAMOCC on could, to a certain extent, contribute to the reduction of this cold bias. However, until a thorough study is carried out, the contribution of other mechanisms cannot be discarded. The SSS simulated by ROM_P0 shows seasonal biases within 1 psu with a similar magnitude and spatial distribution to those in RCSM4 (Sevault et al., 2014). The biases are higher in areas such as the northern Adriatic Sea and the Dardanelles strait (Fig. 9), a feature that has also been shown in previous studies (L'Hévéder et al., 2013; Di Luca et al., 2014; Sevault et al., 2014). The Mediterranean water fluxes simulated by ROM_P0 (Table 4) have been compared to available observations (Sanchez-Gomez et al., 2011; SotoNavarro et al., 2014) and model (Sevault et al., 2014) estimates, providing a physically consistent assessment in the straits. ROM_P0 water balance terms over the Mediterranean Sea are similar to those obtained by different authors (Table 4). The main difference is the exchange flows through the Strait of Gibraltar, where ROM_P0 presents estimates much lower than those shown by Soto-Navarro et al. (2014), although the net flow is in agreement with most estimates.

The ROM_P0 SSH and surface $(31 \mathrm{~m})$ circulation are able to reproduce the different stationary elevation/depression (anticyclonic/cyclonic) structures occurring in the Mediterranean Sea (Fig. 11). The cyclonic gyres (SSH depressions) correspond to the water mass formation sites. For the period 1980-2012, the comparison between ROM_P0 and AVISO (SSALTO/DUACS, 2013) altimetry data (Fig. 12a) produced a satisfactory correlation of 0.61 , similar to that obtained by the RCSM4 (0.68) (Sevault et al., 2014). Finally, the ROM_P0 amplitude of the mean seasonal cycle measured was $12 \mathrm{~cm}$ while for AVISO it was $14.5 \mathrm{~cm}$ (Fig. 12b) and for RCSM4 $16.9 \mathrm{~cm}$ (Sevault et al., 2014).

In general, despite some systematic errors, we have shown that ROM_P0 satisfactorily reproduces the mean state, seasonal cycle and interannual variability shown in the analyzed variables from ERA-Interim (1980-2012). There is a clear improvement over the driving MPI-ESM, and ROM_P0 skills are comparable to other AORCMs. The use of a global ocean grid allows us to overcome the difficult prescription of ocean lateral boundary conditions but also, more importantly, to take into account the possible feedbacks between changes in Mediterranean Sea state and changes in the adjacent North Atlantic and Black Sea, which may be of importance for climate projections, by means of an explicit exchange through the Strait of Gibraltar and the Dardanelles. Adloff et al. (2015) studied the Mediterranean Sea response 
to climate change by means of a set of numerical experiments using the regional ocean model NEMOMED8 and concluded that the sensitivity of the evolution of the Mediterranean water masses to the choice of the Atlantic boundary conditions is at least of the same order as the sensitivity to the choice of the socio-economic scenario. The model also proved capable of reproducing the area-averaged interannual standard deviations of SST for the Mediterranean Sea (Fig. 16d). As seen in Fig. 16, the ROM-coupled system presents yearly SST standard deviations close to the reference OISST dataset. In fact, ROM_P0 does not only improve the yearly spatial standard deviations compared to the MPI-ESMs (Fig. 16e and f) but also compared to ERA-Interim and EN4 (Fig. 16b and c). The MPI-ESM-LR and MPI-ESM-MR are not able to reproduce those local patterns due to the coarse resolution, which indicates that the dynamical downscaling from MPI-ESM refines the fields simulated by the GCMs.

In our simulations, the Mediterranean Sea will be warmer and saltier by the end of the 21 st century. This process is gradual but accelerates in the last third of the century. Under the RCP8.5 scenario, ROM provides integrated estimates of climate change similar to other models (Table 6). The mean $\triangle$ SST projected by ROM under the RCP8.5 scenario is $2.7^{\circ} \mathrm{C}$ (ROM_P2-ROM_P1), close to MPI-ESM simulations, which show an SST increase of $2.8^{\circ} \mathrm{C}$ (MPI-ESM-LR) and $2.9^{\circ} \mathrm{C}$ (MPI-ESM-MR). It is also close to the mean increase $\left(2.6^{\circ} \mathrm{C}\right)$ projected by the CMIP5 ensemble of Shaltout and Omstedt (2014) (Table 6). These SST warming estimates also agree with those obtained by Adloff et al. (2015) using a six-member scenario simulation $\left(3.1^{\circ} \mathrm{C}\right.$ warming $)$ and by Darmakari et al. (2019) using a six-model ensemble (warming from 2.7 to $3.8^{\circ} \mathrm{C}$ ). In contrast, the ROM_P2 projected mean SSS change is much smaller than those estimated by other authors (Somot et al., 2006, 2008; Adloff et al., 2015; see Table 6). This is related to the dipolar structure of the $\triangle$ SSS field (Fig. 13d), pointing to a remarkable salinization in the eastern Mediterranean and a slight freshening in a large fraction of the western basin. This is a direct consequence of the North Atlantic Ocean influence, taken into account through the ROM global ocean component, on the thermohaline fields and circulation in the Mediterranean Sea.

The time evolution of characteristics of Mediterranean water masses shows a warming that initially takes place at the surface and gradually penetrates to deeper layers in both eastern and western basins, while there is also a gradual salinity increase except in the upper $100 \mathrm{~m}$ layer of the western basin where there is a freshening. In the eastern Mediterranean, at depths corresponding to LIW, the warming and salinization accelerate in the last third of the century; this warm and salty signal at intermediate depths subsequently propagates into the western basin. All these changes will have an impact on the Mediterranean thermohaline circulation, which will be addressed in a forthcoming paper.

\section{Conclusions}

In this study, ROM, the atmosphere-ocean regionally coupled model (Sein et al., 2015), was described and validated for the Mediterranean region. The ROM-coupled system has demonstrated benefits compared to other AORCMs without the global ocean. The use of a global ocean model avoids the problems caused by the oceanic boundary conditions and allows for a better understanding of coupling feedbacks between coupled and uncoupled ocean areas (Sein et al., 2015), which is essential for the Mediterranean Sea. Examples include the influence of the Modified Atlantic Water in the surface freshening of the western Mediterranean and the potential impact of the change in properties and production rate of Mediterranean intermediate and deep waters, a mix of which will later exit the Strait of Gibraltar as Mediterranean Outflow Water, spreading through the North Atlantic and contributing, to a certain extent, to the deep water production in the northern seas. This global ocean approach also provides an additional "degree of freedom" in the model setup and tuning, which can be helpful, for example, in adjusting the ocean component for better performance within the region of interest. In terms of climate change projections, the use of a global ocean model could improve AORCMs, which prescribe the global ocean boundary conditions. ROM, as a refined global ocean model coupled with a regional climate change atmospheric model, is able to obtain physically consistent results in the ocean both within and outside of the coupled domain. This prevents the introduction of biases in the results that are typical of regional ocean models, which implement lateral boundary conditions provided by coarser global AORCM scenario simulations (Sein et al., 2015).

The experiment in which our model is driven by ERAInterim shows good performance in simulating the present climate. ROM is able to reproduce the main characteristics of the Mediterranean Sea, providing a physically consistent estimation of the average behavior, seasonal cycle and interannual variability of both atmospheric and oceanic parameters. However, there is place for further improvement in reducing certain biases (SST and MSLP) by isolating the causes through targeted sensitivity experiments. At this point, we have found that an appropriate modification of the optical properties of the water leads to a reduction of SST bias. For instance, the inclusion of a marine biogeochemistry model (i.e., HAMOCC) improves the ROM_P0 SST performance.

The model simulates explicitly the exchange of water through the Straight of Gibraltar and the Dardanelles, taking into account the signals from the neighboring basins (Atlantic Ocean and Black Sea), which are essential to include for the large-scale feedbacks in the climate signal of the Mediterranean. Moreover, ROM shows improvements in reproducing local and mesoscale features in the Mediterranean Sea in contrast to ESMs.

Our analysis of the simulations driven by the MPI-ESM RCP8.5 scenarios shows that by the end of the 21 st century 
the Mediterranean Sea will be warmer and saltier throughout most of the basin. The temperature in the upper ocean layer during the period 2070-2099 will increase by $2.7^{\circ} \mathrm{C}$ in comparison with the 1976-2005 control period while the mean salinity will increase by $0.2 \mathrm{psu}$. The warming that initially takes place at the surface propagates gradually to the deeper layers. Furthermore, it is very remarkable that the western Mediterranean surface layer presents a decreasing salinity tendency, opposite to the rest of the Mediterranean. There is a change in the LIW characteristics, which propagates from the eastern Mediterranean to the west, pointing to MTHC changes in the future.

An important disadvantage of the proposed model is that the biases and internal variability generated in the global domain can influence the results in the coupled domain, making it difficult to separate the sources of bias.

Finally, we conclude that the ROM is a powerful model system that can be used to estimate possible impacts of climate change on regional scales. In the future, we plan to use our ROM-coupled system to characterize and analyze the climate variability of deep water formation in the Mediterranean Sea.

\section{Data availability. The ROM data are avail- able at https://swiftbrowser.dkrz.de/public/dkrz 64ea1a99-f1de-45dab8d1-a3175f15ee46/ROM_MED_dataset/ (Sein et al., 2015). The ERA-Interim data can be found at https://www.ecmwf.int/en/forecasts/datasets/reanalysis-datasets/ era-interim (Dee et al., 2011). The TRMM data were down- loaded from ftp://arthurhou.pps.eosdis.nasa.gov/gpmdata/ (Huff- man et al., 2014). The OISST datasets were downloaded from the NOAA website (https://www.ncdc.noaa.gov/oisst, Reynolds et al., 2007). The EN4 data are available at https://www.metoffice.gov.uk/hadobs/en4/download.html (Good et al., 2013). The MPI-ESMs data were downloaded from https://cera-www.dkrz.de/WDCC/ui/cerasearch/q?query= mpi-esm\&page $=0 \&$ rows $=15$ (Giorgetta et al., 2013). The SSALTO/DUACS altimeter products are produced and distributed by the Copernicus Marine and Environment Monitoring Service (CMEMS) (https://resources.marine.copernicus.eu/?option=com_ csw\&view=details\&product_id=SEALEVEL_GLO_PHY_ \\ L4_REP_OBSERVATIONS_008_047_SSALTO/DUACS, \\ 2013). The MEDSEA_REANALYSIS_PHY_006_009 is also implemented by CMEMS} (https://doi.org/10.25423/MEDSEA_REANALYSIS_PHY_006_009, Fratianni et al., 2015).

Supplement. The supplement related to this article is available online at: https://doi.org/10.5194/os-16-743-2020-supplement.

Author contributions. AI, WC and DS planned and designed the study. IMP-B and RV processed and analyzed the data. DS performed the ROM runs. IMP-B, RV, WC, DS, RM, JP-S and AI contributed with the analysis performance and interpretation of the results. IMP-B prepared everything.

Competing interests. The authors declare that they have no conflict of interest.

Acknowledgements. Simulations were done at the German Climate Computing Center (DKRZ). The constructive criticism of three anonymous referees and the work of the editor have greatly improved the original paper.

Financial support. This paper has been supported by INMAR and by the Spanish National Research Plan through project TRUCO (RTI2018-100865-B-C22), University of Cádiz (ES-Q1132001G). Dmitry Sein was supported by PRIMAVERA funding received from the European Commission under Grant Agreement 641727 of the Horizon 2020 research program and by the state assignment of FASO Russia (theme no. 0149-2019-0015). William Cabos has been funded by the Spanish Ministry of Science, Innovation and Universities, the Spanish State Research Agency, and the European Regional Development Fund through grant CGL2017-89583-R.

Review statement. This paper was edited by Markus Meier and reviewed by three anonymous referees.

\section{References}

Adloff, F., Somot, S., Sevault, F., Jordà, G., Aznar, R., Déqué, M., Herrmann, M., Marcos, M., Dubois, C., Padorno, E., and Alvarez-Fanjul, E.: Mediterranean Sea response to climate change in an ensemble of twenty first century scenarios, Clim. Dynam., 45, 2775-2802, https://doi.org/10.1007/s00382-0152507-3, 2015.

Akhtar, N., Brauch, J., and Ahrens, B.: Climate modeling over the Mediterranean Sea: impact of resolution and ocean coupling, Clim. Dynam, 51, 933-948, https://doi.org/10.1007/s00382-0173570-8, 2018.

Akhtar, N., Krug, A., Brauch, J., Arsouze, T., Dieterich, C., and Ahrens, B.: European marginal seas in a regional atmosphereocean coupled model and their impact on Vb-cyclones and associated precipitation, Clim. Dynam., 53, 5967-5984, https://doi.org/10.1007/s00382-019-04906-x, 2019.

Arakawa, A. and Lamb, V. R.: Computational design of the basic dynamical processes of the UCLA general circulation model, General Circulation of the Atmosphere, 17, 173-265, 1977.

Artale, V., Calmanti, S., Carillo, A., Dell' Aquila, A., Herrmann, M., Pisacane, G., Ruti, P. M., Sannino, G., Struglia, M. V., Giorgi, F., Bi, X., Pal, J. S., and Rauscher, S.: An atmosphere-ocean regional climate model for the Mediterranean area: assessment of a present climate simulation, Clim. Dynam., 35, 721-740, https://doi.org/10.1007/s00382-009-0691-8, 2010.

Bergamasco, A. and Malanotte-Rizzoli, P.: The circulation of the Mediterranean Sea: a historical review of exper- 
imental investigations, Adv. Ocean. Limol., 1, 11-28, https://doi.org/10.1080/19475721.2010.491656, 2010.

Beuvier, J., Sevault, F., Herrmann, M., Kontoyiannis, H., Ludwig, W., Rixen, M., Stanev, E., Béranger, K., and Somot, S.: Modeling the Mediterranean Sea interannual variability during 1961-2000: focus on the Eastern Mediterranean Transient, J. Geophys. Res., 115, C08017, https://doi.org/10.1029/2009JC005950, 2010.

Cabos, W., Sein, D. V., Durán-Quesada, A., Liguori, G., Koldunov, N. V., Martínez-López, B., Alvarez, F., Sieck, K., Limareva, N., and Pinto J. G.: Dynamical downscaling of historical climate over CORDEX Central America domain with a regionally coupled atmosphere-ocean model, Clim. Dynam., 52, 4305-4328, https://doi.org/10.1007/s00382-018-4381-2, 2019.

Cavicchia, L., Gualdi, S., Sanna, A., and Oddo, P.: The Regional Ocean-Atmosphere Coupled Model COSMP-NEMO_MFS, CMCC Res. Paper, RP0254, 2015.

Cramer, W., Guiot, J., Fader, M., Garrabou, J., Gattuso, J-P., Iglesias, A., Lange, M. A., Lionello, P., Llasat, M. C., Paz, S., Peñuelas, J., Snoussi, M., Toreti, A., Tsimplis, M. N., and Xoplaki, E.: Climate change and interconnected risks to sustainable development in the Mediterranean, Nat. Clim. Change, 8, 972-980, https://doi.org/10.1038/s41558-018-0299-2, 2018.

Darmaraki, S., Somot, S., Sevault, F., Nabat, P., Cabos Narvaez, W. D., Cavicchia, L., Djurdjevic, V., Li, L., Sannino, G., and Sein, D. V.: Future evolution of Marine Heatwaves in the Mediterranean Sea, Clim. Dynam., 53, 1371-1392, https://doi.org/10.1007/s00382-019-04661-z, 2019.

Dee, D. P., Uppala, S. M., Simmons, A. J., Berrisford, P., Poli, P., Kobayashi. S., Andrae, U., Balmaseda, M. A., Balsamo, G., Bauer, P., Bechtold, P., Beljaars, A. C. M., van den Berg, L., Bidlot, J., Bormann, N., Delsol, C., Dragani, R., Fuentes, M., Geer, A. J., Haimberger, L., Healy, S. B., Hersbach, H., Hólm, E. V., Isaksen, L., Kallber, P., Kohler, M., Matricardi, M., McNally, A. P., Monge-Sanz, B. M., Morcrett, J. J., Park, B. K., Peubey, C., de Rosnay, P., Tavolato, C., Thépaut, J. N., and Vitart, F.: The ERA-Interim reanalysis: configuration and performance of the data assimilation system, Q. J. Roy. Meteor. Soc., 137, 553-597, https://doi.org/10.1002/qj.828, 2011 (data available at: https://www.ecmwf.int/en/forecasts/datasets/ reanalysis-datasets/era-interim, last access: 13 February 2020).

Dengg, J., Beckmann, A., and Gerdes, R.: The Gulf Stream separation problem, in The Warmwatersphere of the North Atlantic Ocean, edited by: Krauss, W., 253-290, Gebr. Bornträger, Berlin, 1996.

Déqué, M. and Piedelievre, J. P.: Latest issue climate simulation over Europe, Clim. Dynam., 11, 321-339, https://doi.org/10.1007/BF00215735, 1995.

Di Luca, A., Flaounas, E., Drobinski, P., and Lebeaupin-Brossier, C.: The atmospheric component of the Mediterranean Sea water budget in a WRF multi-physics ensemble and observations, Clim. Dynam., 43, 2349-2375, https://doi.org/10.1007/s00382014-2058-z, 2014.

Dubois, C., Somot, S., Calmanti, S., Carillo, A., Déqué, M., Dell'Aquilla, A., Elizalde, A., Gualdi, S., Jacob, D., L'Hévéder, B., Li, L., Oddo, P., Sannino, G., Scoccimarro, E., and Sevault, F.: Future projections of the surface heat and water budgets of the Mediterranean Sea in an ensemble of coupled atmosphereocean regional climate models, Clim. Dynam., 39, 1859-1884, https://doi.org/10.1007/s00382-011-1261-4, 2012.
Fantini, A., Raffaele, F., Torma, C., Bacer, S., Coppola, E., Giorgi, F., Ahrens, B., Dubois, C., Sanchez, E., and Verdecchia, M.: Assessment of multiple daily precipitation statistics in ERAInterim driven Med-CORDEX and EURO-CORDEX experiments against high resolution observations, Clim. Dynam., 51, 877-900, https://doi.org/10.1007/s00382-016-3453-4, 2018.

Fratianni, C., Simoncelli, S., Pinardi, N., Cherchi, A., Grandi, A., and Dobricic, S.: Mediterranean RR 1955-2015 (Version1) [Dataset], Copernicus Monitoring Environment Marine Service (CMEMS), https://doi.org/10.25423/MEDSEA_REANALYSIS_PHY_006, 2015.

Ferster, B. S., Subrahmanyam, B., and Macdonald, A. M.: Confirmation of ENSO-Southern Ocean Teleconnections Using Satellite-Derived SST, Remote Sens., 10, 1-9, https://doi.org/10.3390/rs10020331, 2018.

Giorgetta, M. A., Jungclaus, J., Reick, C. H., Legutke, S., Bader, J., Böttinger, M., Brovkin, V., Crueger, T., Esch, M., Fieg, K., Glushak, K., Gayler, V., Haak, H., Hollweg, H.-D., Ilyina, T., Kinne, S., Kornblueh, L., Matei, D., Mauritsen, T., Mikolajewicz, U., Mueller, W., Notz, D., Pithan, F., Raddatz, T., Rast, S., Redler, R., Roeckner, E., Schmidt, H., Schnur, R., Segschneider, J., Six, K. D., Stockhause, M., Timmreck, C., Wegner, J., Widmann, H., Wieners, K.-H., Claussen, M., Marotzke, J., and Stevens, B.: Climate and carbon cycle changes from 1850 to 2100 in MPI-ESM simulations for the Coupled Model Intercomparison Project phase 5, J. Adv. Model. Earth Sy., 5, 572-597, https://doi.org/10.1002/jame.20038, 2013 (data available at: https://cera-www.dkrz.de/WDCC/ui/ cerasearch/q?query $=$ mpi-esm \&page $=0 \&$ rows $=15$, last access: 6 October 2020).

Giorgi, F.: Climate change hot-spots, Geophys. Res. Lett., 33, L08707, https://doi.org/10.1029/2006GL025734, 2006.

Giorgi, F. and Lionello, P.: Climate change projections for the Mediterranean region, Global Planet. Change, 63, 90-104, https://doi.org/10.1016/j.gloplacha.2007.09.005, 2008.

Good, S. A., Martin, M. J., and Rayner, N. A.: EN4: Quality controlled ocean temperature and salinity profiles and monthly objective analyses with uncertainty estimates, J. Geophys. Res.-Oceans, 118, 6704-6716, https://doi.org/10.1002/2013JC009067, 2013 (data available at: https://www.metoffice.gov.uk/hadobs/en4/download.html).

Gouretski, V. and Reseghetti, F.: On depth and temperature biases in bathythermograph data: Development of a new correction scheme based on analysis of a global ocean database, Deep-Sea Res. Pt. I., 57, 812-833, https://doi.org/10.1016/j.dsr.2010.03.011, 2010.

Gualdi, S., Somot, S., Li, L., Artale, V., Adani, M., Bellucci, A., Braun, A., Calmanti, S., Carillo, A., Dell'Aquila, A., Déqué, M., Dubois, C., Elizalde, A., Harzallah, A., Jacob, D., L'Hévéder, B., May, W., Oddo, P., Ruti, P., Sanna, A., Sannino, G., Scoccimarro, E., Sevault, F., and Navarra, A.: The CIRCE simulations: regional climate change projections with realistic representation of the Mediterranean Sea, B. Am. Meteorol. Soc., 94, 65-81, https://doi.org/10.1175/BAMS-D-11-00136.1, 2013.

Hagemann, S. and Dümenil-Gates, L.: A parameterization of the lateral waterflow for the global scale, Clim. Dynam., 14, 17-31, https://doi.org/10.1007/s003820050205, 1998. 
Hagemann, S. and Dümenil-Gates, L.: Validation of the hydrological cycle of ECMWF and NCEP reanalysis using the MPI hydrological discharge model, J. Geophys. Res., 106, 1503-1510, https://doi.org/10.1029/2000JD900568, 2001.

Hibler III, W. D.: A dynamic thermodynamic sea ice model, J. Phys. Oceanogr., 9, 815-846, https://doi.org/10.1175/15200485(1979)009<0815:ADTSIM>2.0.CO;2, 1979.

Huffman, G., Bolvin, D., Braithwaite, D., Hsu, K., Joyce, R., and Xie, P.: Integrated Multi-satellitE Retrievals for GPM (IMERG), version 4.4. NASA's Precipitation Processing Center, available at: ftp://arthurhou.pps.eosdis.nasa.gov/gpmdata/ (last access: 31 March 2015), 2014.

Ilyina, T., Six, K., Segschneider, J., Maier-Reimer, E., Li, H., and Nunez-Riboni, I.: Global ocean biogeochemistry model HAMOCC: Model architecture and performance as component of the MPI-Earth System Model in different CMIP5 experimental realizations, J. Adv. Model. Earth Sy., 5, 287-315, https://doi.org/10.1029/2012MS000178, 2013.

IPCC: Emissions Scenarios. Summary for Policymakers. A special Report of IPCC Working Group III, Cambridge University Press, Cambridge, 2000.

Izquierdo, A. and Mikolajewicz, U.: The role of tides in the spreading of Mediterranean Outflow waters along the southwestern Iberian margin, Ocean Model., 133, 27-43, https://doi.org/10.1016/j.ocemod.2018.08.003, 2019.

Jacob, D.: A note to the simulation of the annual and interannual variability of the water budget over the Baltic Sea drainage basin, Meteorol. Atmos. Phys., 77, 61-73, https://doi.org/10.1007/s007030170017, 2001.

Jungclaus, J. H., Fischer, N., Haak, H., Lohmann, K., Marotzke, J., Matei, D., Mikolajewicz, U., Notz, D., and von Storch, J. S.: Characteristics of the ocean simulations in MPIOM, the ocean component of the MPI-Earth system model, J. Adv. Model Earth Sy., 5, 422-446, https://doi.org/10.1002/jame.20023, 2013.

Lauer, A., Eyring, V., Righi, M., Buchwitz, M., Defourny, P., Evaldsson, M., Friedlingstein, P., de Jeu, R., de Leeuw, G., Loew, A., Merchant, C. J., Müler, B., Popp, T., Reuter, M., Sandven, S., Senftleben, D., Stengel, M., Van Roozendael, M., Wenzel, S., and Willén, U.: Benchmarking CMIP5 models with a subset of ESA CCI Phase 2 data using the ESMValTool, Remote Sens. Environ., 203, 9-39, https://doi.org/10.1016/j.rse.2017.01.007, 2017.

Levitus, S., Boyer, T. P., Conkright, M. E., O’Brien, T., Antonov, J., Stephens, C., Stathoplos, L., Johnson, D., and Gelfeld, R.: World Ocean Database 1998, vol.1, Introduction, NOAA Atlas NESDIS 18, Ocean Clim. Lab., Natl. Oceanogr. Data Cent., U.S. Gov. Print. Off., Washington, D.C., 1998.

L'Hévéder, B., Li, L., Sevault, F., and Somot, S.: Interannual variability of deep convection in the Northwestern Mediterranean simulated with a coupled AORCM, Clim. Dynam., 41, 937-960, https://doi.org/10.1007/s00382-012-1527-5, 2013.

Li, H., Kanamitsu, M., and Hong, S. Y.: California reanalysis downscaling at $10 \mathrm{~km}$ using an ocean-atmosphere coupled regional model system, J. Geophys. Res., 117, D12118, https://doi.org/10.1029/2011JD017372, 2012.

Macias, D., Garcia-Gorriz, E., Dosio, A., Stips, A., and Keuler, K.: Obtaining the correct sea surface temperature: bias correction of regional climate model data for the Mediterranean Sea, Clim. Dynam., 51, 1095-1117, https://doi.org/10.1007/s00382016-3049-z, 2018.
Maier-Reimer, E., Kriest, I., Segschneider, J., and Wetzel, P.: The HAMburg Ocean Carbon Cycle Model HAMOCC5.1 Technical Description Release 1.1, Ber. Erdsystemforschung, 14, available at: http://hdl.handle.net/11858/00-001M-0000-0011-FF5C-D (last access: 24 November 2019), 2005.

Majewski, D.: The Europa-Modell of the Deutscher Wetterdienst, Seminar Proceedings ECMWF, Reading, 2, 147-191, 1991.

Marsland, S. J., Haak, H., Jungclaus, J. H., Latif, M., and Roeske, F.: The Max-Planck- Institute global ocean/sea ice model with orthogonal curvilinear coordinates, Ocean Model., 5, 91-127, https://doi.org/10.1016/S1463-5003(02)00015-X, 2003.

Menna, M. and Poulain, P. M.: Mediterranean intermediate circulation estimated from Argo data in 2003-2010, Ocean Sci., 6, 331-343, https://doi.org/10.5194/os-6-331-2010, 2010

Metzger, E. J., Smedstad, O. M., Thoppil, P. G., Hurlburt, H. E., Cummings, J. A., Wallcraft, A. J., Zamudio, L., Franklin, D. S., Posey, P. G., Phelps, M. W., Hogan, P. J., Bub, F, L., and DeHaan, C. J.: US Navy Operational Global Ocean and Artic Ice Prediction Systems, Oceanography, 27, 32-43, https://doi.org/10.5670/oceanog.2014.66, 2014.

Panthou, G., Vrac, M., Drobinski, P., Bastin, S., and Li, L.: Impact of model resolution and Mediterranean Sea coupling on hydrometeorological extremes in RCMs in the frame of HymMeX and MED-CORDEX, Clim. Dynam., 51, 915-932, https://doi.org/10.1007/s00382-016-3374-2, 2018.

Rechid, D. and Jacob, D.: Influence of monthly varying vegetation on the simulated climate in Europe, Meteorol. Z., 15, 99-116, https://doi.org/10.1127/0941-2948/2006/0091, 2006.

Reick, C. H., Raddatz, T., Brovkin, V., and Gayler, V.: The representation of natural and anthropogenic land cover change in MPIESM, J. Adv. Model. Earth Sy., 5, 1-24, https://doi.org/10.1002/jame.20022, 2013.

Reynolds, R. W., Smith, T. M., Liu, C., Chelton, D. B., Casey, K. S., and Schlax, M. G.: Daily High-Resolution-Blended Analyses for sea surface temperature, J. Climate, 20, 5473-5496, https://doi.org/10.1175/2007JCLI1824.1, 2007 (data available at: https://www.ncdc.noaa.gov/oisst, last access: 6 October 2020).

Roeckner, E., Arpe, K., Bengtsson, L., Christoph, M., Claussen, M., Dümenil, L., Esch, M., Giorgetta, M., Schlese, U., and Schulzweida, U.: The Atmospheric General Circulation Model ECHAM-4: Model description and simulation of present-dayclimate, Rep. 218, MPI für Meteorol., Hamburg, Germany, 1996.

Roeckner, E., Bäuml, G., Bonaventura, L., Brokopf, R., Esch, M., Giorgetta, M., Hagemann, S., Kirchner, I., Kornblueh, L., Manzini, E., Schlese, U., and Schulzweida, U.: The atmospheric general circulation model ECHAM 5. PART I: Model description, Rep. 349, MPI für Meteorol., Hamburg, Germany, available at: http://hdl.handle.net/11858/00-001M-0000-0012-0144-5 (last access: 17 February 2019), 2003.

Ruti, P. M., Somot, S., Giorgi, F., Dubois, C., Flaounas, E., Obermann, A., Dell'Aquila, A., Pisacane, G., Harzallah, A., Lombardi, E., Ahrens, B., Akhtar, N., Alias, A., Arsouze, T., Aznar, R., Bastin, S., Bartholy, J., Béranger, K., Beuvier, J., BouffiesCloché, S., Brauch, J., Cabos, W., Calmanti, S., Calvet, J. C., Carillo, A., Conte, D., Coppola, E., Djurdjevic, V., Dobrinski, P., Elizalde-Arellano, A., Gaertner, M., Galan, P., Gallardo, C., Gualdi, S., Goncalves, M., Jorba, O., Jorda, G., L'Heveder, B., Lebeaupin-Brossier, L., Li, L., Liguori, G., Lionello, P., Macias, D., Nabat, P., Önol, B., Raikovic, B., Ramage, K., 
Sevault, F., Sannino, G., Struglia, M. V., Sanna, A., Troma, C., and Vervatis, V.: MED-CORDEX initiative for Mediterranean Climate studies, B. Am. Meteorol. Soc., 97, 1187-1208, https://doi.org/10.1175/BAMS-D-14-00176.1, 2015.

Sánchez-Gómez, E., Somot, S., Josey, S. A., Dubois, C., Elguindi, N., and Déqué, M.: Evaluation of Mediterranean Sea water and heat budgets simulated by an ensemble of high resolution regional climate models, Clim. Dynam., 37, 2067-2086, https://doi.org/10.1007/s00382-011-1012-6, 2011.

Sein, D. V., Koldunov, N. V., Pinto, J. G., and Cabos, W.: Sensitivity of simulated regional Arctic climate to the choice of coupled model domain, Tellus A, 66, 23966, https://doi.org/10.3402/tellusa.v66.23966, 2014.

Sein, D. V., Mikolajewicz, U., Gröger, M., Fast, I., Cabos, W., Pinto, J. G., Hagemann, S., Semmler, T., Izquierdo, A., and Jacob, D.: Regionally coupled atmosphere-oceansea ice-marine biogeochemistry model ROM: 1. Description and validation, J. Adv. Model. Earth Sy., 7, 268-304, https://doi.org/10.1002/2014MS000357, 2015.

Sevault, F., Somot, S., Alias, A., Dubois, C., LebeaupinBrossier, C., Nabat, P., Adloff, F., Déqué, M., and Decharme, B.: A fully coupled Mediterranean regional climate system model: design and evaluation of the ocean component for the 1980-2012 period, Tellus A, 66, 23967, https://doi.org/10.3402/tellusa.v66.23967, 2014.

Shaltout, M. and Omstedt, A.: Recent sea surface temperature trends and future scenarios for the Mediterranean Sea, Oceanologia, 56, 411-443, https://doi.org/10.5697/oc.56-3.411, 2014.

Simmons, A. J. and Burridge, D. M.: An energy and angular-momentum conserving vertical finite-difference scheme and hybrid vertical coordinate, Mon. Weather. Rev., 109, 758-766, https://doi.org/10.1175/15200493(1981)109<0758:AEAAMC>2.0.CO;2, 1981.

Somot, S., Sevault, F., and Déqué, M.: Transient climate change scenario simulation of the Mediterranean Sea for the 21st century using a high-resolution ocean circulation model, Clim. Dynam., 27, 851-879, https://doi.org/10.1007/s00382-006-0167-z, 2006.

Somot, S., Sevault, F., Déqué, M., and Crépon, M.: 21 st century climate change scenario for the Mediterranean using a coupled atmosphere-ocean regional climate model, Global Planet. Change, 63, 112-126, https://doi.org/10.1016/j.gloplacha.2007.10.003, 2008.

Somot, S., Ruti, P., Ahrens, B., Coppola, E., Jordà, G., Sannino, G., and Solmon, F.: Editorial for the Med-CORDEX special issue, Clim. Dynam., 51, 771-777, https://doi.org/10.1007/s00382018-4325-x, 2018.

Soto-Navarro, J., Somot, S., Sevault, F., Beuvier, J., CriadoAldeanueva, F., García-Lafuente, J., and Béranger, K.: Evaluation of regional ocean circulation models for the Mediterranean Sea at the Strait of Gibraltar: volume transport and thermohaline properties of the outflow, Clim. Dynam., 44, 1277-1292, https://doi.org/10.1007/s00382-014-2179-4, 2014.
SSALTO/DUACS: User Handbook (M)SLA and (M)ADT nearreal time and delayed time products. Nomenclature: SALPMU-P-EA-21065-CLS. Issue 3, Rev. 4. Reference: CLSDOSNT-06-034, available at: https://resources.marine.copernicus. eu/?option=com_csw\&view=details\&product_id=SEALEVEL_ GLO_PHY_L4_REP_OBSERVATIONS_008_047 (last access: 22 June 2020), 2013.

Stevens, B., Giorgetta, M., Esch, M., Mauritsen, T., Crueger, T., Rast, S. Salzmann, M., Schmidt, H., Bader, J., Block, K., Brokopf, R., Fast, I., Kinne, S., Kornblueh, L., Lohmann, U., Pincus, R., Reichler, R., and Roeckner, E.: Atmospheric component of the MPI-M Earth system model: ECHAM6, J. Adv. Model. Earth Sy., 5, 146-172, https://doi.org/10.1002/jame.20015, 2013.

Struglia, M. V., Mariotti, A., and Filograsso, A.: River discharge into the Mediterranean Sea: climatology and aspects of the observed variability, J. Climate, 17, 4740-4751, https://doi.org/10.1175/JCLI-3225.1, 2004.

Tanre, D., Geleyn, J. F., and Slingo, J. M.: First results of the introduction of an advanced aerosol-radiation interaction in the ECMWF low resolution global model, Aerosols and their Climatic Effects, edited by: Gerber, H. and Deepak, A., Hampton, Virginia, 133-177, 1984.

Taylor, K., Stouffer, R., and Meehl, G.: An overview of CMIP5 and the experiments design, B. Am. Meteorol. Soc., 93, 485-498, https://doi.org/10.1175/BAMS-D-11-00094.1, 2012.

Thorpe, R. B. and Bigg, G. R.: Modelling the sensitivity of the Mediterranean outflow to anthropogenically forced climate change, Clim. Dynam., 16, 355-368, https://doi.org/10.1007/s003820050333, 2000.

Tomczak, M. and Godfrey S. J.: Regional Oceanography: an Introduction, Pergamon, New York, 274-280, 1994.

Valcke, S.: The OASIS3 coupler: a European climate modelling community software, Geosci. Model Dev., 6, 373-388, https://doi.org/10.5194/gmd-6-373-2013, 2013.

Velikou, K., Tolika, K., Anagnostopoulou, C., and Zanis, P.: Sensitivity analysis of RegCM4 model: present time simulations over the Mediterranean, Theor. Appl. Climatol., 136, 1185-1208, https://doi.org/10.1007/s00704-018-2547-9, 2019.

Wang, F. and Polcher, J.: Assessing the freshwater flux from the continents to the Mediterranean Sea, Sci. Rep.-UK, 9, 8024, https://doi.org/10.1038/s41598-019-44293-1, 2019. 